TITLE:

\title{
A STUDY ON THE ECHINOID FAUNA OF THE EAST CHINA SEA AND THE COASTAL WATERS OF SOUTHERN KOREA, KYUSHU, RYUKYU, AND TAIWAN
}

\section{$\operatorname{AUTHOR}(\mathrm{S})$ :}

Shigei, Michio

\section{CITATION:}

Shigei, Michio. A STUDY ON THE ECHINOID FAUNA OF THE EAST CHINA SEA AND THE COASTAL WATERS OF SOUTHERN KOREA, KYUSHU, RYUKYU, AND TAIWAN.

PUBLICATIONS OF THE SETO MARINE BIOLOGICAL LABORATORY 1981, 26(1-3): 191-241

\section{ISSUE DATE:}

1981-03-30

URL:

http://hdl.handle.net/2433/176013

RIGHT: 


\title{
A STUDY ON THE ECHINOID FAUNA OF THE EAST GHINA SEA AND THE COASTAL WATERS OF SOUTHERN KOREA, KYUSHU, RYUKYU, AND TAIWAN
}

\author{
Mranio SHIGEI \\ Misaki Marine Biological Station, Faculty of Science, Tokyo University
}

With Text-figures $1-13$ and Tables 1-9

\section{Introduction}

I have recently had chances to examine a large number of echinoid specimens collected from various localities which cover so wide a range as to enable a faunal or zoogeographical study of the East China Sea and its adjacent waters.

The topography and the marine environmental condition of the present region are as follows:

The East China Sea spreads from the Chinese coast eastward to southwestern Japan. There is Korea to the north, Kyushu to the east, Ryukyu to the southeast to south, and Taiwan to the southernmost. It connects with the Pacific Ocean through a chain of islands arranged in an arc, the Nansei-Shoto Group which includes the Ohsumi, the Amami, the Okinawa, the Miyako, and the Yaeyama Groups. The floor of the East China Sea is widely occupied in its western part by the Chinese continental shelf. Southeastwardly it deepens toward the Ryukyus forming a wide bathyal zone, called the Okinawa Trough, which reaches to ca. $2,500 \mathrm{~m}$ at its deepest point. On the Pacific side of the Ryukyus, the sea floor abruptly deepens to form the Ryukyu Trench which reaches to ca. 7,800 $\mathrm{m}$ at its deepest point (Fig. 1).

The ocean currents and water masses in the East China Sea and its adjacent waters are shown in Figure 2. Among the warm waters, the Kuroshio current is most prominent and dominates the oceanographical condition of the southern and southeastern part of the East China Sea. It flows from the east coast of Taiwan northeastward along the edge of the continental shelf. In the north of AmamiOhshima Island (ca. $29^{\circ} 5^{\prime} \mathrm{N}$., $129^{\circ} \mathrm{E}$.), it leaves the edge of the continental shelf gradually, turning to the east, and finally flows out to the Pacific Ocean through the Tokara Strait. The axis of this current is stable and rarely undulates. It carries $20-60 \times 10^{6} \mathrm{~m}^{3}$ water mass per second at the speed of 1.5-3.0 knot per hour; and its salinity is $34.0-34.5 \%$ (Inoue, 1974).

The Tsushima current, a large branch of the Kuroshio, begins at the point where the Kuroshio leaves the edge of the continental shelf. It flows at about 0.5-1.5 knot per hour northward in the area off western Kyushu and west of the Goto

Publ. Seto Mar. Biol. Lab., XXVI (1/3), 191-241, 1981. (Article 12) 
Islands, and finally flows into the Japan Sea through the Tsushima- and Korea Straits. The axis of this current is stated to deviate somewhat between west and east, or undulates under the influence of the cold water mass of the Yellow Sea, the coastal water of the Chinese Continent, and the coastal water of Kyushu (Tsujita, 1957; Inoue, 1974; Ogawa et al., 1978). The water of this current is mainly composed of the Kuroshio water and waters upwelled along the edge of the continental shelf

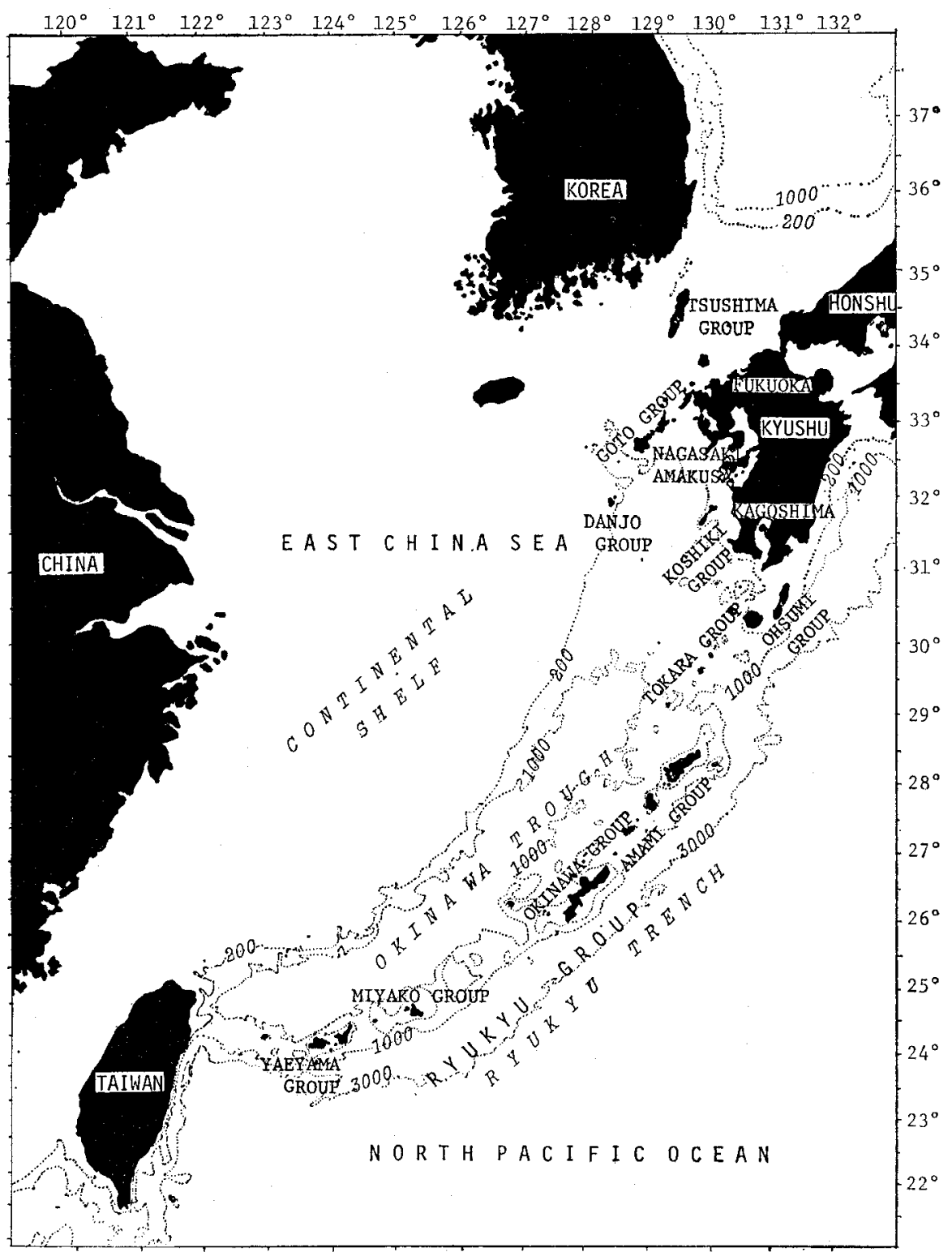

Figure 1. A map of the whole region (depth lines are drawn based on the nautical chart, No. 1004A, Hydrographic Division Office, Maritime Safety Agency, Japan, 1977). 


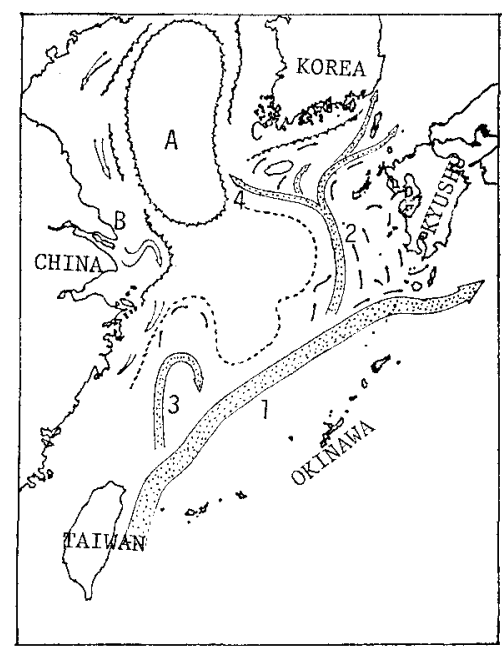

Figure 2. Currents and water masses in the East China Sea and its adjacent waters (modified from Inoue, N., 1974).

1-4, warm waters. A-C, cold waters. 1-Kuroshio current; 2 Tsushima current; 3-Median warm current; 4-Yellow Sea warm current; A-Cold water mass in the Yellow Sea; B-Coastal water of the Chinese Continent; C-Coastal water of the Korea Peninsula.

from depths of 50-200 $\mathrm{m}$ (Inoue 1974).

The median warm current is a branch of the Kuroshio and the Yellow Sea current is a branch of the Tsushima current. These branches are greatly influenced by the coastal waters of the Chinese Continent and the cold water mass of the Yellow Sea respectively, and seasonal variations of current conditions are fairly large.

There is a large, cold water mass in the Yellow Sea. The water temperature of the mass rises in early summer only up to $10-15^{\circ} \mathrm{G}$ (at a depth of $50 \mathrm{~m}$ ). Seasonal variation of the surface temperature is stated to be $14-19^{\circ} \mathrm{C}$ (Kikuchi, 1968).

The coastal water of the Ghinese Continent is also cold in winter and its salinity is very low. However, the water temperature and salinity are variable in different areas and different seasons, according to the condition of the subaerial climate of the Chinese Continent.

In winter, these cold water masses become particularly massive and spread widely toward the southeastern part of the continental shelf as far as the area of ca. $30^{\circ} \mathrm{N}$., $127^{\circ} \mathrm{E}$. . The seasonal, northwest wind takes part in this spreading.

The coastal water of southern part of the Korea Peninsula lies in the area north of a line drawn from off the northern coasts of Cheju Island to the Tsushima Islands. There occurs a distinct front between this water mass and the Tsushima current.

The coastal water of Kyushu is stated to become especially massive in the rainy season in Japan (June-July) and influences the direction and composition of the Tsushima current. 
The temperature and salinities of these warm and cold waters differ considerably from each other, and they remain fairly independent, with little intermixing (Kikuchi, 1968; Inoue, 1974). However, in the areas on the southeastern to middle portion of the continental shelf, the cold waters from the Yellow Sea and the Chinese Continent and the warm water from the Tsushima current are mixed to some extent. In such areas, the salinities are stated to be 33.5-34.0\% (Inoue, 1974).

\section{Materials and Methods}

The data on species and localities are mostly based on the results of my examination of the preserved specimens and my field surveys during the years of 1974-76 and 78, however, those on 17 species and from 19 localities are taken from Döderlein (1885), Ohshima (1934), Hayasaka (1948), Tokioka (1955), and Matsubayashi (1973). The methods of the faunal analysis are based on my thesis for the doctor's degree and Shigei (1970a, 1970b, 1971, 1973a, 1973b, 1973c, 1974, 1975a, 1975b, 1975c, 1977a, 1977b).

The sources of the preserved specimens examined in the present study are as follows:

The Misaki Marine Biological Station Collection Series I (from the intertidal \& upper sublittoral zone).

Series A: Collector; Michio Shigei. Localities; Kyushu (Fukuoka, Nagasaki, Amakusa, and Kagoshima), Ohsumi Group (Tane and Yaku Isls.), Amami Group (Amami-Ohshima and Okinocrabu Isls.), Okinawa Isl., Miyako Isl., Yaeyama Group (Ishigaki, Taketomi, Kuroshima, Haderuma, and Yonaguni Isls.), and Taiwan (Chi-lung). Number of specimens; 138. Number of species; 27. Years of collecting; 1974-76, 1978, 1980.

Series B: Collector; Moritaka Nishihira of the Department of Zoology, Faculty of Science, Kyoto University. Localities; Okinawa and Ishigaki Isls. Number of specimens; 22. Number of species; 16. Years of collecting; 1972, 1974-75.

Series C: Collector; Kiyoshi Yamazato of the Department of Biology, Faculty of Science, Ryukyu University. Localities; Okinawa and Ishigaki Isls. Number of specimens; 18. Number of species; 10. Years of collecting; 1960's.

Series D: Collector; Ki Won Kim of the Department of Biology, Liberal Arts and Science College, Chonnam University. Localities; Southern Korea (Nammyun Yoolrim-ri, Tolsan-myon, and Cheju Isl.). Number of specimens; 40. Number of species; 8. Years of collecting; 1975, 1978, 1979.

Series E: Collector; Ten Shau Tan of the Department of Zoology, National Taiwan University. Locality; Taiwan (Ghi-lung). Number of specimens; 32. Number of species; 5. Years of collecting; 1975.

Series F: Kinzo Matsubayashi of the Biological Society of Nagasaki Prefecture. Locality; Nagasaki (Nomo). Number of specimens; 4. Number of species; 4. Years of collecting; 1966, 1974. 
Series G-K: Collectors; Taiji Kikuchi of the Amakusa Marine Biological Station (G), Takao Yamaguchi of the Aitsu Marine Biological Station (H), Hiroshi Mukai and Suguru Ohta of the Ocean Research Institute of Tokyo University (I), Hideo Nakamura of the Sesoko Marine Biological Station (J), and Shonan Amemiya of the Misaki Marine Biological Station (K). Localities; Amakusa, Ishigaki Isl., and Okinawa (Sesoko) Isl. Number of specimens; 23. Number of species; 9. Years of collecting; 1964, 1975-76, 1978, 1980.

The Misaki Marine Biological Station Collection Series II (mainly from the lower sublittoral to bathyal zones).

Series L: Collectors; Shuzo Kishida and Tadahiro Kitajima of the Seikai Regional Fisheries Laboratory. Research vessels; Yüryo-Maru No. 8 and RyoanMaru No. 28. Localities and Depths; the Okinawa Trough and partly the continental shelf, 125-1,130 m. Number of stations; 28. Number of specimens; 68. Number of species; 18. Year of collecting; 1978.

Series M: Collector; Hideo Yamashita of the Seikai Regional Fisheries Research Laboratory. Research vessels; the Yokō-Maru and the Kaiyö-Maru. Localities and Depths; northern Kyushu (shelf zone), western Kyushu (shelf zone), southern Kyushu (shelf zone and partly upper bathyal zone), submarine banks, and the continental shelf, 32-430 m. Number of stations; 27. Number of specimens; 101. Number of species; 26. Years of collecting; 1962-64, 1966-67, 1971, 1975.

Series N: Collector; Katsura Oyama of the Toba Aquarium. Research vessels; the Tokaidaigaku-Maru. II and the Wakashio. Localities and Depths; northern Kyushu (shelf zone), western Kyushu (shelf- and upper bathyal zone), and partly southern Kyushu (shelf- and upper bathyal zone), 38-580 m. Number of stations 20. Number of specimens; 48. Number of species; 18 . Years of collecting; 197273.

Series O: Gollector; Takashi Okutani of the National Science Museum. Research vessel; the Sōyō-Maru. Localities and Depths; southern Kyushu, submarine banks, and partly the continental shelf, the Okinawa Trough, and the Ryukyu sea shelf, 48-1,240 m. Number of stations; 19. Number of specimens; 55. Number of species; 28. Years of collecting; 1957, 1959-60, 1964-65, 1972-73, 1976-1978.

Series P: Collector; Tohru Imaoka of the Seto Marine Biological Laboratory. Research vessels; the Kagoshima-Maru and many fishing boats. Localities and Depths; southern Kyushu (shelf zone and partly upper bathyal zone), 20-380 m. Number of stations; 8. Number of specimens; 62. Number of species; 27. Years of collecting; 1973-75.

Series Q: Collector; Yoshiaki Tominaga of the University Museum, Tokyo University. Research vessels; fishing boats. Localities and Depths; uncertain (shelf zone of the East China Sea). Number of stations; 5 . Number of specimens;

13. Number of species; 4 . Year of collecting; 1974.

Collection Series in the laboratory other than the M.M.B.S.

Series R: Laboratory; the Department of Zoology, Faculty of Agriculture, Kyushu University. Collectors; Hayato Ikeda, Hiroshi Ohshima, and many others. 
Localities; Southern Korea, Kyushu (Fukuoka, Nagasaki, and Amakusa), Fukue-, Amami-Oshima-, Okinawa-, Ishigaki-, Haderuma Isl., and Taiwan; intertidal zone and partly shelf zone. Number of specimens; about 300. Number of species; 50. Years of collecting; 1929, 1932-35, 1937, 1953, 1956, 1958.

${ }^{\circ}$ Series S: Laboratory; the Seikai Regional Fisheries Research Laboratory. Collector; Hideo Yamashita. Localities; northern Kyushu (shelf zone), western Kyushu (shelf zone), southern Kyushu (shelf zone, submarine banks, and partly upper bathyal zone), and the continental shelf. Number of specimens; 101. Number of species; 26. Years of collecting; 1962-64, 1966-67, 1971, 1975.

${ }^{\circ}$ Series T: Laboratory; the Amakusa Marine Biological Station. Collectors; Taiji Kikuchi and partly Hiroshi Ohshima. Localities; Amakusa, intertidal \& upper sublittoral zone and partly lower sublittoral zone. Number of specimens; about 120. Number of species; 24. Years of collecting; 1928, 1931-32, 1940, 1962-69, 1975-76.

Series U: Laboratory; the Department of Zoology, University Museum, Tokyo University. Collectors; Shigeyasu Tokunaga and many others. Localities; Kyushu (Fukuoka, Nagasaki, and Kagoshima), Amami-Ohshima- and Okinawa Isl., intertidal-subtidal zone. Number of specimens; about 100. Number of species; 15. Years of collecting; 1896-1903.

Series V: Laboratory; the Department of Marine Ecology, Ocean Research Institute, Tokyo University. Collectors: Masuoki Horikoshi and Suguru Ohta. Research Vessel: Hakuho-Maru. Localities: the continental shelf (2 loc.), the Okinawa Trough (1 loc.), and the Ryukyu sea shelf (3 loc.). Number of specimens: 84. Number of species: 12. Years of collecting: 1968 (KH-68-2), 1973 (KH-73-2), 1974 (KH-74-3).

${ }^{\circ}$ Series W: Laboratory; the Department of Biology, Faculty of Science, Ryukyu University. Collector; Kiyoshi Yamazato. Localities; Okinawa- and Ishigaki Isl., intertidal-subtidal zone. Number of specimens; 35 . Number of species; 10. Years of collecting; 1960's.

Series X: Laboratory; the Amami Laboratory of Medical Zoology, Institute of Medical Science, Tokyo University. Collector; Yoshihiro Hayashi. Localities; Amami-Ohshima Isl., intertidal zone. Number of specimens; 20. Number of species; 9. Year of collecting; 1977.

Series Y: Laboratory; the Imperial Household. Collectors; uncertain. Localities; Amami-Ohshima- and Okinawa Isl. Number of specimens; 11 . Number of species; 8. Years of collecting; 1927, 1935.

${ }^{\circ}$ Series Z: Laboratory; the Department of Zoology, National Taiwan University. Collectors; Ten Shau Tan and others. Locality; Taiwan (Chi-lung). Number of specimens; about 100. Number of species; 5. Year of collecting; 1975.

The series marked by a small circle include some specimens which have been donated to the M.M.B.S. collection series. 


\section{Systematics}

Systematic studies were made first and the results are used as the basic data for faunal studies.

Through the examination of the specimens, 112 species were found. From the literature, additional 17 species (asterisked in the following list) were added in the fauna. A total of 129 species of 89 genera, 35 families and 9 orders are classified as follows:

$$
\begin{aligned}
& \text { Order CIDAROIDA Glaus } \\
& \text { Family Cidaridae Gray } \\
& \text { Subfamily Histocidarinae Mortensen } \\
& \text { Genus Histocidaris Mortensen, } 1903
\end{aligned}
$$

1. H. carinata Mortensen, 1928

Subfamily Goniocidarinae Mortensen

Genus Goniocidaris L. Agassiz and Desor, 1846

Subgenus Petalocidaris Mortensen, 1903

2. G. (P.) biserialis (Döderlein, 1885)

Subgenus Discocidaris Döderlein, 1885

3. G. (D.) midako (Döderlein, 1885)

Subgenus Aspidocidaris Mortensen, 1928

4. G. (A.) clypeata Döderlein, 1885

5. G. (A.) alba Mortensen, 1928

Subgenus Cyrtocidaris Mortensen, 1927

6. G. (C.) sp. nov.

Genus Rhopalocidaris Mortensen, 1927

7. R. rosea Mortensen, 1928

Subfamily Stereocidarinae Lambert

Genus Stereocidaris Pomel, 1883

Subgenus Stereocidaris Pomel, 1883

8. S. (S.) grandis (Döderlein, 1885)

9. S. (S.) indica philippinensis Mortensen, 1928

10. *S. (S.) sceptriferoides Döderlein, 1887

Subgenus Phalacrocidaris Lambert, 1902

11. S. (P.) japonica (Döderlein, 1885)

Genus Compsocidaris Ikeda, 1939

12. C. pyrsacantha Ikeda, 1939

Subfamily Stylocidarinae Mortensen

Genus Acanthocidaris Mortensen, 1903

13. A. maculicolis (Meijere, 1903)

Genus Stylocidaris Mortensen, 1909

14. S. reini (Döderlein, 1887)

15. S. annulosa Mortensen, 1927

16. S. maculosa Mortensen, 1928 
17. S. ryukyuensis Shigei, 1975

Genus Chorocidaris Ikeda, 1941

18. C. fussispina (Mortensen, 1928)

Genus Eucidaris Pomel, 1883

19. E. metularia (Lamarck, 1816)

Genus Plococidaris Mortensen, 1909

20. P. verticillata (Lamarck, 1816)

Genus Prionocidaris A. Agassiz, 1863

21. P. baculosa annulifera (Lamarck, 1816)

22. P. australis (Ramsay, 1885)

Subfamily Rhabdocidarinae Mortensen

Genus Phyllacanthus Brandt, 1835

23. P. imperialis (Lamarck, 1816)

Order LEPIDOGENTROIDA Mortensen

Family Echinothuridae Thomson

Subfamily Phormosominae Mortensen

Genus Phormosoma Thomson, 1872

24. P. bursarium A. Agassiz, 1881

Subfamily Kamptosominae Mortensen

Genus Kamptosoma Mortensen, 1903

25. K. asterias (A. Agassiz, 1881)

Subfamly Echinothuriinae Thomson

Genus Sperosoma Koehler, 1897

26. S. giganteum A. Agassiz and H.L. Clark, 1907

Genus Hygrosoma Mortensen, 1903

27. H. hoplacantha (Thomson, 1877)

Genus Calveriosoma Mortensen, 1934

28. C. gracile (A. Agassiz, 1881)

Genus Araeosoma Mortensen, 1903

29. A. oustoni Mortensen, 1904

Genus Hapalosoma Mortensen, 1903

30. H. gemmiferum Mortensen, 1934

Genus Asthenosoma Grube, 1867

31. A. ijimai Yoshiwara, 1887

Order DIADEMATOIDA Duncan

Suborder ASPIDODIADEMINA Mortensen

Famliy Aspidodiadematidae Duncan

Genus Aspidodiadema A. Agassiz, 1879

32. A. tonsum A. Agassiz, 1879

33. A. intermedium Shigei, 1977

Suborder DIADEMINA Duncan

Family Diadematidae Gray

Genus Astropyga Gray, 1825 
34. A. radiata (Leske, 1778)

Genus Eremopyga A. Agassiz and H.L. Clark, 1908

35. E. denudata (Meijere, 1902)

Genus Chaetodiadema Mortensen, 1903

36. C. japonicum Mortensen, 1904

Genus Diadema Humphrey, 1797

37. D. setosum (Leske, 1778)

38. D. savignyi (Audouin, 1828)

Genus Echinothrix Peters, 1853

39. E. calamaris (Pallas, 1774)

40. E. diadema (Linnaeus, 1758)

Suborder PEDININA Mortensen

Family Pedinidae Pomel

Genus Caenopedina A. Agassiz, 1869

41. C. mirabilis (Döderlein, 1885)

42. C. indica (Meijere, 1903)

Order ARBACIOIDA Gregory

Suborder SALENINA Mortensen

Family Saleniidae L. Agassiz

Genus Salenia Gray, 1835

43. S. cincta A. Agassiz and H.L. Clark, 1907

Suborder ARBACINA Gregory

Family Arbaciidae Gray

Genus Coelopleurus L. Agassiz, 1840

44. C. maculatus A. Agassiz and H.L. Clark, 1907

45. C. undulatus Mortensen, 1934

Suborder PHYMOSOMATINA Mortensen

Family Stomopneustidae Mortensen

Genus Stomopneustes L. Agassiz, 1841

46. S. variolaris (Lamarck, 1816)

Order ECHINOIDA Claus

Suborder TEMNOPLEURINA Mortensen

Family Temnopleuridae A. Agassiz

Subfamily Temnopleurinae A. Agassiz

Genus Temnopleurus L. Agassiz, 1841

Subgenus Temnopleurus L. Agassiz, 1841

47. T. (T.) toreumaticus (Leske, 1778)

48. T. (T.) hardwickii (Gray, 1855)

Subgenus Toreumatica Gray, 1855

49. $T$. (T.) reevesii (Gray, 1855)

50. T. (T.) apodus (A. Agassiz and H.L. Clark, 1907)

Genus Salmaciella Mortensen, 1942

51. S. dussumieri (L. Agassiz, 1846)

Genus Microcyphus L. Agassiz, 1841 
52. M. olivaceus (Döderlein, 1885)

Genus Mespilia Desor, 1846

53. M. globulus (Linnaeus, 1758)

54. M. levituberculatus Yoshiwara, 1898

Genus Temnotrema A. Agassiz, 1863

55. T. sculptum A. Agassiz, 1863

Subfamily Trigonocidarinae Mortensen

Genus Opechinus Desor, 1856

56. *O. variabilis (Döderlein, 1885)

Genus Prionechinus A. Agassiz, 1879

57. *P. forbesianus (A. Agassiz, 1881)

Genus Lamprechinus Döderlein, 1905

58. *L. sculptus Mortensen, 1942

Family Toxopneustidae Troschel

Genus Nudechinus H.L. Clark, 1912

59. N. multicolor (Yoshiwara, 1898)

Genus Toxopneustes L. Agassiz, 1841

60. T. pileolus (Lamarck, 1816)

61. T. elegans Döderlein, 1885

Genus Tripneustes L. Agassiz, 1841

62. T. gratilla (Linnaeus, 1758)

Genus Pseudoboletia Troschel, 1869

63. P. maculata Troschel, 1869

Suborder ECHININA Claus

Family Echinidae Gray

Genus Echinus Linnaeus, 1758

64. E. lucidus Döderlein, 1885

Family Strongylocentrotidae Gregory

Genus Strongylocentrotus Brandt, 1835

65. S. nudus (A. Agassiz, 1863)

Genus Hemicentrotus Mortensen, 1942

66. H. pulcherrimus (A. Agassiz, 1863)

Genus Pseudocentrotus Mortensen, 1903

67. P. depressus (A. Agassiz, 1863)

Family Echinometridae Gray

Genus Echinostrephus A. Agassiz, 1863

68. E. aciculatus A. Agassiz, 1863

69. E. molaris (Blainville, 1825)

Genus Anthocidaris Lütken, 1864

70. A. crassispina (A. Agassiz, 1863)

Genus Echinometra Gray

71. E. mathaei (Blainville, 1825)

Genus Heterocentrotus Brandt, 1835 
72. H. mammillatus (Linnaeus, 1758)

Genus Colobocentrotus Brandt, 1835

73. C. mertensii Brandt, 1835

Family Parasaleniidae Mortensen

Genus Parasalenia A. Agassiz, 1863

74. P. gratiosa A. Agassiz, 1863

Order HOLEGTYPOIDA Duncan

Suborder EGHINONEINA Hawkins

Family Echinoneidae Wright

Genus Echinoneus Leske, 1778

75. E. cyclostomus Leske, 1778

Genus Micropetalon A. Agassiz and H.L. Clark, 1907

76. $M$. sp. nov.

Order GASSIDULOIDA Glaus

Suborder NEOLAMPADINA Philip

Family Neolampadidae Lambert

Genus nov.

77. Genus and sp. nov.

Suborder CASSIDULINA Claus

Family Pliolampadidae Kier

Genus Oligopodia Duncan, 1889

78. O. epigona (Martens, 1865)

Family Echinolampadidae Gray 1825

Genus Echinolampas Gray, 1825

79. E. koreana H.L. Clark, 1925

80. E. sternopetala A. Agassiz and H.L. Clark, 1907

Order CLYPEASTEROIDA A. Agassiz

Suborder CLYPEASTERINA A. Agassiz

Family Clypeasteridae L. Agassiz

Genus Clypeaster Lamarck, 1801

81. C. virescens Döderlein, 1885

82. C. japonicus Döderlein, 1885

83. C. ohshimensis Ikeda, 1936

84. C. fervens Koehler, 1922

85. *C.reticulatus (Linnaeus, 1758)

Family Arachnoididae Duncan

Genus Arachnoides Leske, 1778

86. *A. placenta (Linnaeus)

Souborder LAGANINA Mortensen

Family Fibulariidae Gray

Genus Fibularia Lamarck, 1816

87. F. ovulum Lamarck, 1816 
88. F. sp. nov.

Genus Fibulariella Mortensen, 1948

89. F. acuta (Yoshiwara, 1898)

Genus Echinocyamus Van Phelsum, 1774

90. *E. crispus Mazzetti, 1893

91. E. subconicus Mortensen, 1948

Family Laganidae Desor

Genus Laganum Link, 1807

92. L. fudsiyama Döderlein, 1885

Genus Peronella Gray, 1855

93. P. lesueuri (Valenciennes, 1841)

94. P. japonica Mortensen, 1948

95. P. rubra Döderlein, 1885

96. P. pellucida Döderlein, 1885

Family Scutellidae Gray

Genus Scaphechinus A. Agassiz, 1863

97. S. mirabilis A. Agassiz, 1863

Family Astriclypeidae Stefanini

Genus Echinodiscus Leske, 1778

98. *E. auritus Leske, 1778

99. E. tenuissimus (L. Agassiz, 1847)

Genus Astriclypeus Verrill, 1867

100. A. manni Verrill, 1867

Order SPATANGOIDA Claus

Suborder URECHININA Hawkins

Family Holasteridae Pictet

Genus Stereopneustes Meijere, 1903

101. S. relictus Meijere, 1903

Family Pourtalesiidae A. Agassiz

Genus Pourtalesia A. Agassiz, 1869

102. *P. laguncula A. Agassiz, 1879

Suborder SPATANGINA Claus

Family Hemiasteridae H.L. Clark

Genus Hemiaster Desor, 1847

103. *H. expergitus gibbosus A. Agassiz, 1881

Family Palaeostomatidae Lovén

Genus Palaeostoma Lovén, 1872

104. *P. mirabile (Gray, 1851)

Family Pericosmidae Lambert

Genus Pericosmus L. Agassiz, 1847

105. P. cordatus Mortensen, 1950

Family Schizastridae Lambert

Genus Faorina Gray 1851 
106. F. chinensis Gray, 1851

Genus Schizaster L. Agassiz, 1836

107. S. lacunosus (Linnaeus, 1758)

108. S. sp. nov.

Genus Moira A. Agassiz, 1872

109. M. lachesinella Mortensen, 1930

Family Aeropsidae Lambert

Genus Aceste Thomson, 1877

110. *A. ovata A. Agassiz and H.L. Clark, 1907

Family Brissidae Gray

Genus Brissopsis L. Agassiz, 1840

111. *B. luzonica (Gray, 1851)

Genus Gymnopatagus Döderlein, 1901

112. G. magnus A. Agassiz and H.L. Clark, 1907

Genus Brissus Gray, 1825

113. B. latecarinatus (Leske, 1778)

114. B. agassizii Döderlein, 1885

Genus Metalia Gray, 1855

115. M. spatagus (Linnaeus, 1758)

116. M. dicrana H.L. Clark, 1917

Family Spatangidae Gray

Subfamily Spatanginae Gray

Genus Saptangus Müller, 1776

117. S. paucituberculatus A. Agassiz and H.L. Clark, 1907

Subfamily Maretiinae Lambert

Genus Pseudomaretia Koehler, 1914

118. P. alta (A. Agassiz, 1863)

119. P. tylota (H.L. Glark, 1917)

Genus Maretia Gray, 1855

120. *M. planulata (Lamarck, 1816)

Family Loveniidae Lambert

Subfamily Loveniinae Lambert

Genus Lovenia Desor, 1847

121. L. elongata (Gray, 1845)

122. L. gregalis Alcock, 1893

123. L. triforis Koehler, 1914

Genus Homolampas A. Agassiz, 1874

124. H. lovenioides Mortensen, 1948

Subfamily Echinocardiinae Cooke

Genus Echinocardium Gray, 1825

125. E. cordatum (Pennant, 1777)

Family Asterostomatidae Pictet

Genus Linopneustes A. Agassiz, 1881 
126. L. fragilis (Meijere, 1904)

127. *L. murrayi (A. Agassiz, 1879)

Genus Argopatagus Agassiz, 1879

128. *A. vitreus A. Agassiz, 1879

129. *A. planus (A. Agassiz and H.L. Clark, 1907)

The species and subspecies placed as synonyms in the present study are as follows (the valid names are shown by the species number in the above list):

Goniocidaris crassa Mortensen-syn. of No. 5

Stereocidaris grandis hyatorina Mortensen and Stereocidaris microtuberculata (Yoshiwara) -syns. of No. 8

Stylocidaris fussispina Mortensen-syn. of No. 18

Prionocidaris glandulosa (Meijere)-syn. of No. 22

Asthenosoma tessellatum A. Agassiz reported by A. Agassiz and H.L. Clark (1907b) [non. Araeosoma tessellatum (A. Agassiz)] and Asthenosoma pyrochloa (A. Agassiz and H.L. Clark)—syns. of No. 28

Asthenosoma owestoni A. Agassiz and H.L. Clark and Asthenosoma bicolor A. Agassiz and H.L. Clark-syns. of of No. 29

Asthenosoma pellucidum A. Agassiz reported by A. Agassiz and H.L. Clark (1907b) (non. A. pellucidum A. Agassiz) - syn. of No. 30

Diadema clarki Ikeda-syn. of No. 37

Hemipedina mirabilis Döderlein-syn. of No. 41

Coelopleurus undulatus polymorphus Mortensen-syn. of No. 45

Temnopleurus reynaudi A. Agassiz-syn. of No. 49

Salmacopsis olivacea Döderlein-syn. of No. 52

Pleurechinus variegatus Mortensen-syn. of No. 55

Pleurechinus variabilis Döderlein-syn. of No. 56

Prionechinus ruber A. Agassiz and H.L. Clark-syn. of No. 57

Parasalenia gratiosa boninensis Mortensen-syn. of No. 74

Echinocyamus scaber subconicus Mortensen-syn. of No. 91

Laganum diploporum A. Agassiz and H.L. Clark-syn. of No. 92

Scaphechinus brevis (Ikeda)--syn. of No. 97

Schizaster japonicus A. Agassiz-syn. of No. 107

Aceste purpurea A. Agassiz and H.L. Clark-syn. of No. 110

Brissopsis oldhami Alcock reported by A. Agassiz and H.L. Clark (1907b) (non. B. oldhami Alcock) - syn. of No. 111

Palaeopneustes fragilis Meijere-syn. of No. 126

Linopneustes excentricus Meijere reported by A. Agassiz and H.L. Clark (1907b) (non. L. excentricus Meijere)-syn. of No. 127

Meijerea excentrica A. Agassiz and H.L. Clark-syn. of No. 128

Meijerea plana A. Agassiz and H.L. Clark-syn. of No. 129 


\section{The Vertical Distribution}

Vertical distributions of species in the present region are shown in Fig. 3 based on the data as follows:

My examination of the Specimen Series A-Z and field surveys, Nos. 1-9, 11-55, 59-84, 87-89, 91-97, 99-101, 105-109, 112-119, 121-126; Mortensen (1928b), No. 10; A. Agassiz and H.L. Clark (1907b), Nos. 56, 57, 102, 103, 110, 111, 127-129; Mortensen (1943a), No. 58; Hayasaka (1948), Nos. 85, 86, 98; Mortensen (1948d), No. 90; Döderlein (1885), Nos. 104, 120.

It is fairly clearly seen in Fig. 3 that the vertical distribution of each species falls into three groups in general: $0-$ ca. $30 \mathrm{~m}$; ca. $30-200 \mathrm{~m}$; and ca. $200-3 ; 500 \mathrm{~m}$. These depth ranges just correspond to the well-known, vertical zones for the marine faunas (Ekman, 1953; Hedgepeth, 1957; Pérès, 1961; Horikoshi, 1962 a-b, 1971; Zenkevitch, 1963; Briggs, 1974). In the present paper, each zone is described as the intertidal \& upper sublittoral, the lower sublittoral, and the bathyal zone. Among these, the upper and lower sublittoral zones can be united as the shelf zone (Ekman, 1953).

The species found in each of these zones are as follows:

Shelf zone:

1) Intertidal \& Upper sublittoral zone: Nos. 19, 20, 21, 23, 31, 34, 37, 38, 39, 40, $46,47,48,51,53,54,59,60,61,62,63,65,66,67,68,69,70,71,72,73,74,75$, $82,83,85,86,87,88,89,93,94,95,97,98,99,100,107,108,109,113,114,115$, $116,118,120,121,125$.

2) Lower sublittoral zone: Nos. 2, 3, 4, 6, 7, 11, 13, 14, 15, 16, 17, 18, 19, 21, 22, $29,30,35,36,41,43,44,45,48,49,50,52,55,56,76,77,78,79,80,81,84,90$, $91,92,96,104,105,106,107,118,121,122,123,125$.

\section{Bathyal zone:}

Nos. $1,5,8,9,10,12,14,18,24,25,26,27,28,32,33,41,42,57,58,64,92,101$, $102,103,105,110,111,112,117,119,124,126,127,128,129$.

The following species overlap between the upper and lower sublittoral zones (their deepest occurrence is shown by depth in parenthesis):

No. $118(-51 \mathrm{~m})$; No. $125(-77 \mathrm{~m})$; No. $121(-82 \mathrm{~m})$; No. $19(-120 \mathrm{~m})$; No. $48(-120 \mathrm{~m})$; No. $21(-130 \mathrm{~m})$; No. $107(-145 \mathrm{~m})$.

For these 7 species $(7.1 \%$ of the total), the boundary between the upper and the lower sublittoral zones seems to be meaningless. However, for the other 92 species $(92.9 \%$ of the total), this boundary is meaningful.

The following species overlap between the lower sublittoral and the bathyal zones (their deepest occurrence is shown by depth in parenthesis):

No. $41(-230 \mathrm{~m})$; No. $92(-280 \mathrm{~m})$; No. $105(-208 \mathrm{~m})$; No. $14(-310 \mathrm{~m})$; No. $18(-400 \mathrm{~m})$.

These species are rare in the bathyal zone, where they occur only in the upper 


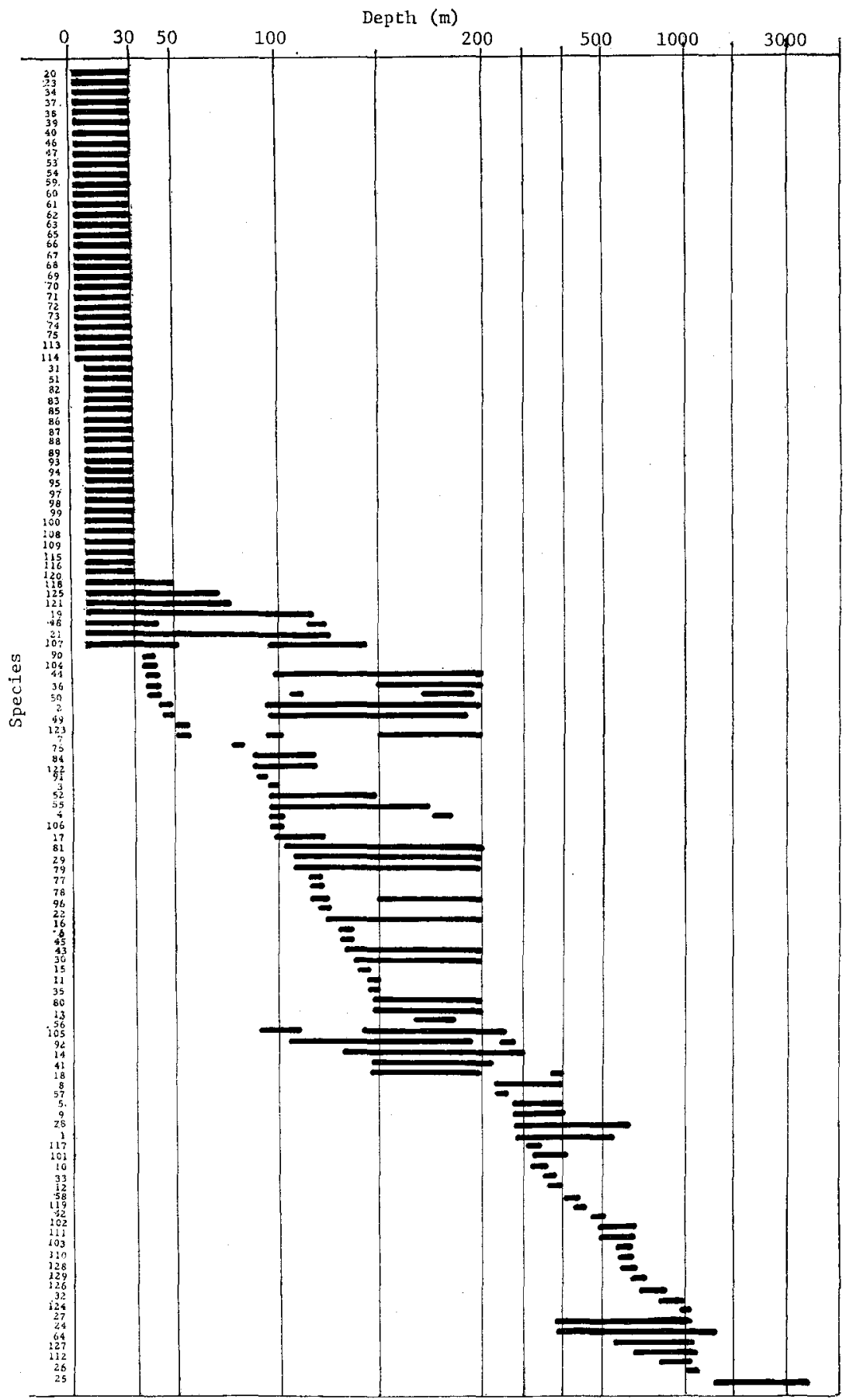

Figure 3. Vertical distributions of species in the present region. Species are shown by the species numbers given in the systematic list. 
part of the upper bathyal zone. Therefore, they may be best considered as shelf elements. If these species are excluded from the bathyal elements, the bathyal fauna can be said to be perfectly independent from the others. Even if these species are included, the shelf and bathyal zones are clearly demarcated by the distribution of the other 124 species.

\section{Studies on the Faunal Elements}

\section{1) Shelf species}

Distributions of the shelf species in Japan and the Indo-West Pacific seas are shown in Fig. 4 based on the following data:

For Japan and its adjacent seas (areas A-L), the data are based on the results of my examination of specimens from various sources (Shigei, unpublished), except those for area A on Nos. II, III (Baranova, 1957); area F on Nos. 18 (Mortensen, 1928b), 56 (Döderlein, 1885); area G on Nos. 11, 14, 92 (Morishita, 1969), 56, 81, 92 (A. Agassiz and H.L. Glark, 1907b) ; area I on Nos. 2, 3, 11, 19-21, 29, 31, 34, $36,39-41,44,47,49-51,54,72-75,80-82,85,89,90,94,96,100,107,114,121$, 125 (Utinomi, 1954). For the Indo-West Pacific seas (areas M-Q), the data are taken from A. Agassiz (1881), A. Agassiz and H.L. Clark (1907 a-b, 1908, 1909), H.L. Clark (1912, 1914, 1917, 1925), Döderlein (1885, 1887, 1906), Koehler (1914, 1922), Meijere (1904), Mortensen (1903, 1904 a bb, 1907, 1927, 1928 b, 1935, 1940 a-b, 1943a-b, 1948b-d, 1950b, 1951).

From Fig. 4, the following four patterns of distribution can be seen.

Pattern 1; distributional range from A (Sakhalin-Kuriles) or B (northeastern Hokkaido) to as far south as E (Kashima Nada).

Pattern 2; distributional range from $\mathrm{G}$ (southwestern Hokkaido) to as far south as $\mathrm{F}$ (Sagami Bay) (rarely to $\mathrm{M}$ ) or $\mathrm{K}$ (Kyushu).

Pattern 3; distributional range from $\mathrm{F}$ (Sagami Bay) to $\mathrm{K}$ (Kyushu) (rarely to $\mathrm{G}$ or in $\mathrm{F}$ alone).

Pattern 4; broad distributional range in M-Q (Indo-West Pacific seas) extending as far north as K (Kyushu), I (Kii Peninsula), or F (Sagami Bay).

The submarine climate in each of the above distributional ranges has been well known as follows; subarctic in pattern 1, temperate (or cold-temperate) in pattern 2, subtropical (or warm-temperate) in pattern 3, and tropical (partly subtropical) in pattern 4.

Based on these facts and the data in Fig. 4, the shelf species are classified as the faunal elements as follows:

Subarctic elements; None (Nos. I-VIII).

Temperate (or cold-temperate) elements; Nos. 48, 65, 66, 97, 125.

Subtropical elements (someone may be warm-temperate elements); Nos. 2, 3, $4,7,11,18,29,30,36,41,45,52,54,55,56,61,67,70,79,80,82,88,94,96,105$, $107,109,114$. 
Distribution areas

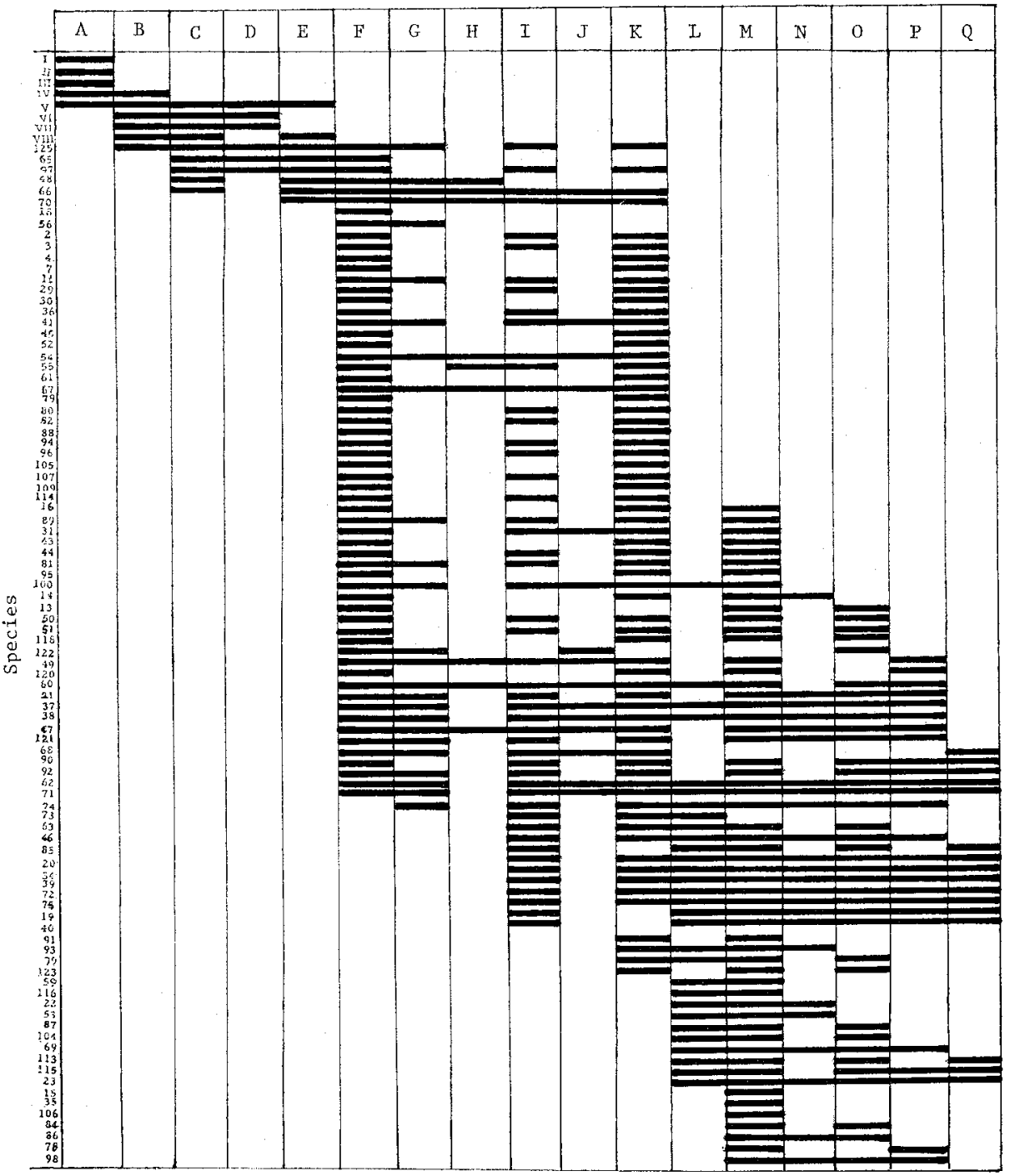

Figure 4. Distributions of the shelf species in Japan and the Indo-West Pacific seas. Species are shown by the species numbers given in the systematic list.

Roman numerals indicate the following species which are added for a comparison:

I-Strongylocentrotus polyacanthus A. AGASsIz and H.L. CLARK; II-Strongylocentrotus droebachiensis (MüLlER); III-Strongylocentrotus pulchellus A. Agassiz and H.L. ClaRK: IV-Echinarachnius parma (LAMARCK); V-Strongylocentrotus sachalinicus DöDERLEIN: VI-Strongylocentrotus intermedius (A. Agassiz); VII-Scaphechinus griseus (MoRtensen); VIII-Glyplocidaris crenularis A. Agassiz. Distribution area:

A-Sakhalin and Kurile Islands; B-Northern and eastern Hokkaido; C-Southwestern Hokkaido; D-Sanriku; E-Kashima Nada; F-Sagami Bay; G-Suruga Bay; H-Shima; I-Kii Peninsula (southernmost part); J-Tosa Bay; K-Kyushu; L-Okinawa; M-Southeast Asia; N-Northern Australia; O-Indian Ocean; P-East Africa; Q-Hawaii. 
Tropical elements; Nos. 13, 14, 15, 16, 19, 20, 21, 22, 23, 31, 34, 35, 37, 38, 39, $40,43,44,46,47,49,50,51,53,59,60,62,63,68,69,71,72,73,74,75,77,78$, $81,84,85,86,87,89,90,91,92,93,95,98,99,100,104,106,113,115,116,118$, $120,121,122,123$.

Endemic (or uncertain) elements; Nos. 6, 17, 76, 83, 108.

2) Bathyal species

Distributions of the bathyal species in the world seas are shown in Fig. 5 based on the following data:

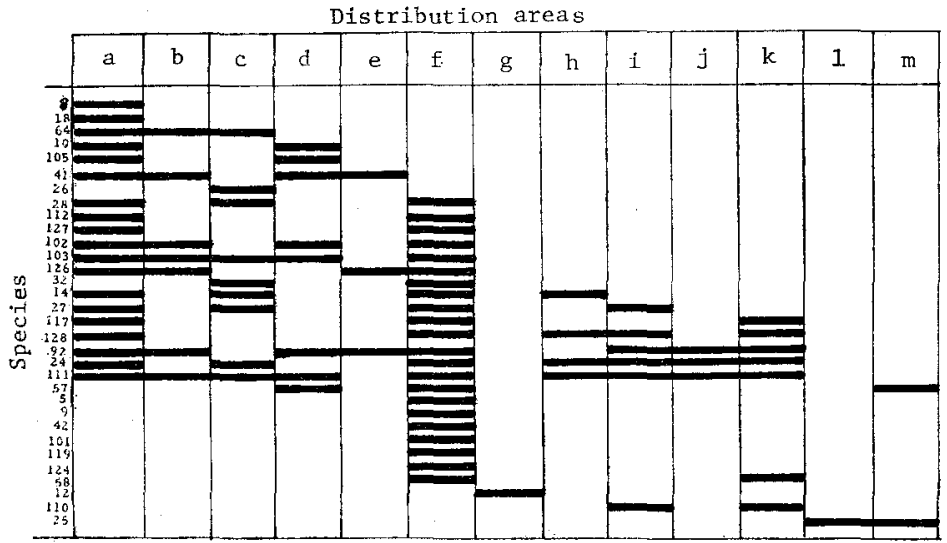

Figure 5. Distributions of the bathyal species in the world seas.

Species are shown by the species number given in the systematic list. Distribution areas:

a-Sagami Bay; b-Suruga Bay; c-off eastern part of Central Japan; d-off Kii Peninsula; e-Tosa Bay; f-Ogasawara sea; g-Southeast Asia; hNorthern Australia; i-Indian Ocean; j-East Africa; k-Hawaii; l-Gentral Pacific; m-Southeastern Pacific.

For Japanese seas (areas a-f), the data are based on the results of my examination of specimens from various sources (Shigei, unpublished), except those for area a on Nos. 18 (Mortensen, 1928b), 127 (A. Agassiz, 1881), 128 (A. Agassiz and H.L. Clark, 1907b); area b on Nos. 102, 103 (A. Agassiz and H.L. Clark, 1907b); area c on Nos. 24, 26-28, 32, 64, 103, 111 (A. Agassiz and H.L. Clark, 1907b); area d on Nos. 10, 41, 57, 92, 102, 103, 111 (A. Agassiz and H.L. Clark, 1907b). For the Indo-West Pacific seas (areas g-m), the data are taken from A. Agassiz (1881), Agassiz and H.L. Clark (1907a-b, 1908, 1909), H.L. Clark (1912, 1914, 1917, 1925), Döderlein (1885, 1887, 1906), Koehler (1914, 1922), Meijere (1904), Mortensen (1903, 1904a-b, 1907, 1927, 1928b, 1935, 1940a-b, 1943a-b, 1948b-d, 1950b, 1951).

As for the bathyal elements, climatological definition can not be applied. In the present paper, the species which have been known only from the areas a-e are tentatively described as the Japanese element. From Fig. 5, each species is classified as the faunal element as follows: 
Japanese elements (someone may be ubiquitous); Nos. 8, 10, 18, 26, 41, 64, 105.

Endemic (or uncertain) elements; Nos. 1, 33, 129.

Ubiquitous elements; Nos. 5, 9, 12, 14, 24, 25, 27, 28, 32, 42, 57, 58, 92, 101, $102,103,110,111,112,117,119,124,126,127,128$.

\section{The Intertidal \& Upper Sublittoral Fauna}

The localities where the specimens from the intertidal \& upper sublittoral zone were collected are shown in maps (Figs. 6-7).

The result of the specimen examination is shown as a table (Tab. I).

The data in Table 1 were rearranged for the faunal analysis, and are shown as a figure of geographical distributions of the intertidal \& upper sublittoral species (Fig. 8).

Based on Figure 8, there can be drawn three lines which show sharp boundary to the distribution patterns of several species. The locations of such lines and the zoogeographical significance of the lines may be as follows:

Line 1 is drawn between area A (the Korea Peninsula) and areas B (Cheju Island)-G (the Tsushima Group):

The northernmost localities of such subtropical species as Nos. 67 (Pseudocentrotus depressus), 70 (Anthocidaris crassispina), 88 (Fibularia n. sp.), 89 (Fibulariella acuta), 54 (Mespilia levituberculatus), 114 (Brissus agassizii) and 82 (Clypeaster japonicus), and such tropical species as Nos. 31 (Asthenosoma ijimai), 60 (Toxopneustes pileolus), 118 (Pseudomaretia alta) and 37 (Diadema setosum) are in areas B or G (Fig. 8).

Such temperate species as Nos. 48 (Temnopleurus hardwickii) and 65 (Strongylocentrotus nudus) become very rare in the south of this line: the former reappears in the lower sublittoral zone of the eastern portion of the continental shelf (see next chapter) and the latter occurs, though rarely, in the Tsushima Group.

Line 2 is drawn between area $\mathrm{I}$ (the Ohsumi Group) and area J (the Tokara Group) :

The southernmost localities of such temperate species as Nos. 66 (Hemicentrotus pulcherrimus) and 125 (Eichinocardium cordatum), and such subtropical species as Nos. 67 (Pseudocentrotus depressus), 70 (Anthocidaris crassispina) and 82 (Clypeaster japonicus) are in area I.) The genus of Echinostrephus found in the north of this line is No. 68 (E. aciculatus), while that found in the south (except Taiwan) is No. 69 (E. molaris) (Fig. 8).

The southernmost localities of such temperate species as No. 97 (Scaphechinus mirabilis), and such subtropical species as Nos. 107 (Schizaster lacunosus), 54 (Mespilia levituberculatus), 114 (Brissus agassizii), and 61 (Toxopneustes elegans) may be in area $\mathrm{H}$

1) I made field surveys at the shore of Yaku and Tane Islands in 1978: Nos. 66, 125, and 67 were very rare; No. 70 was rather common; and No. 68 was common. None of these species were found at the Amami, the Okinawa and the Yaeyama Groups during my surveys in 1974-76, and 1978. 


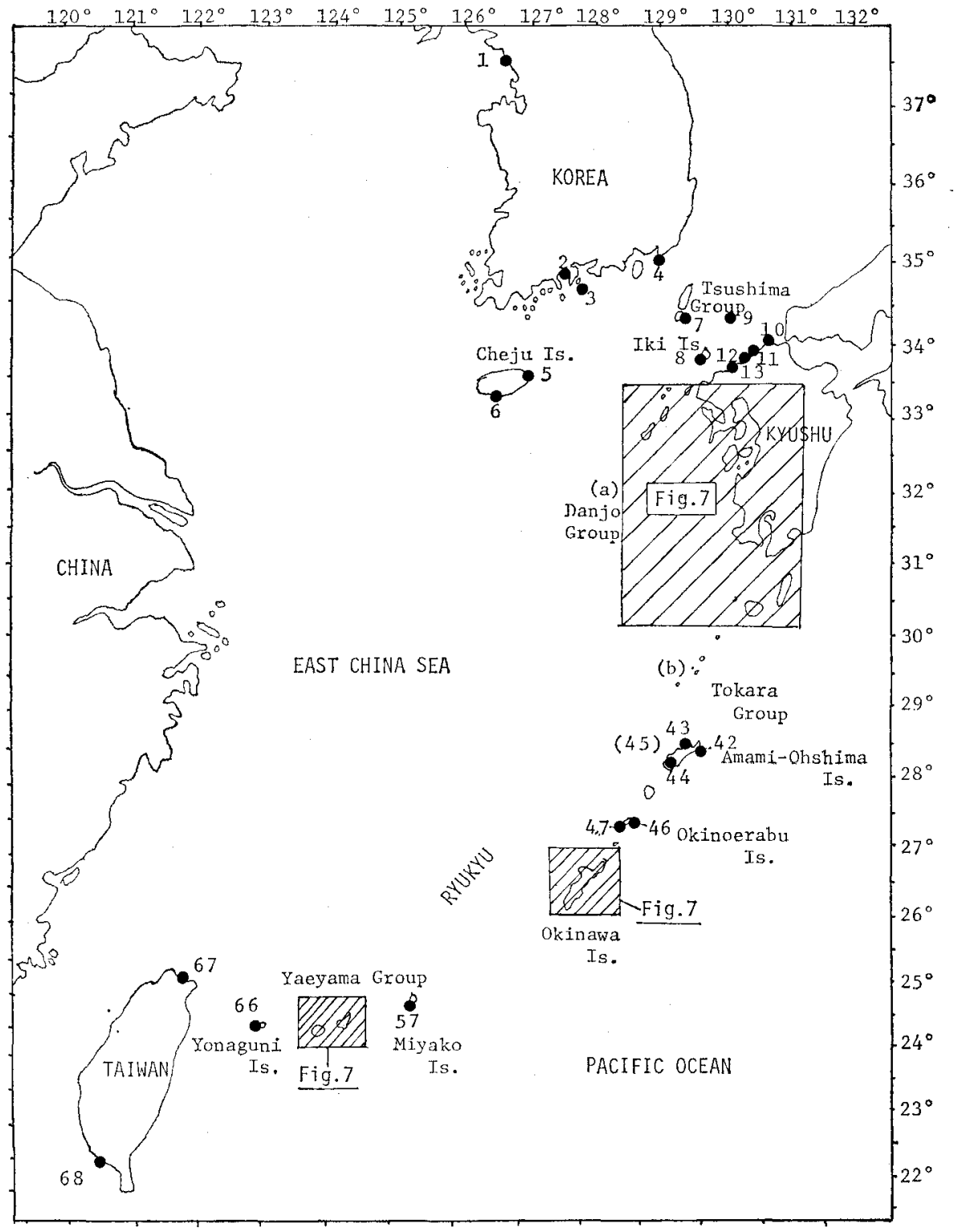

Figure 6. A map of the whole region showing the locations where the specimens from the intertidal \& upper sublittoral zone were collected.

1-Inchon; 2-Nam-myun Yoolrim-ri; 3-Tolsan-myon; 4-Pusan; 5-Sungsanpo; 6-Sukipo; 7-Izuhara; 8-Gonoura; 9-Okinoshima 10-Iwaya; 11-Tsuyazaki; 12-Hakata Bay; 13Keya; 42-Yoh (Kasari); 43-Naze; 44-Koniya; 45-uncertain (Amami-Ohshima); 6Wadomari; 47-Tina; 57-Kuruma; 66-Hikawa; 67-Chi-lung; 68-Kao-hsiung; a-Mejima; b-Nakanoshima and Takarajima. 


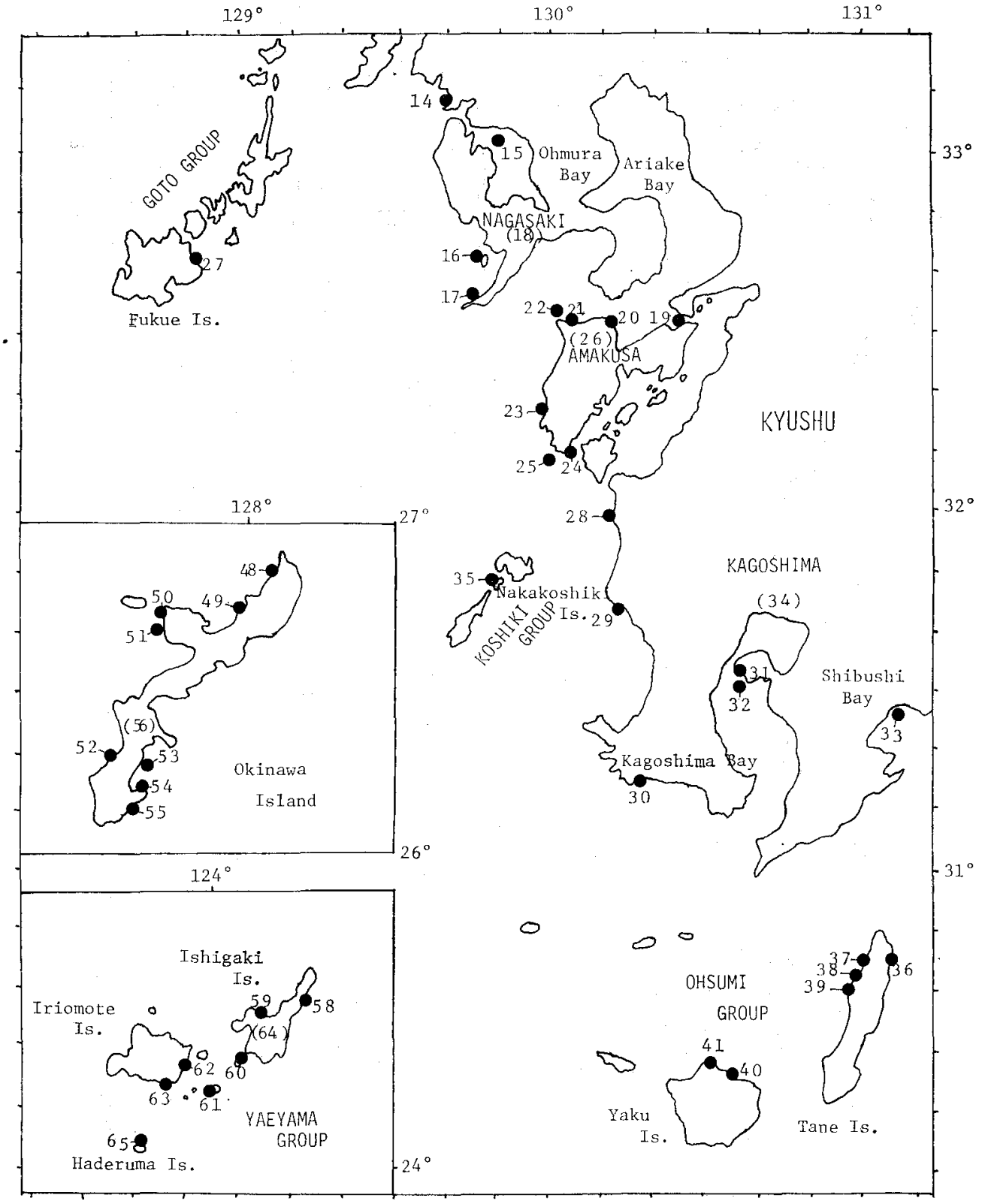

Figure 7. Enlarged maps of the areas in Fig. 6 showing the locations where the specimens from the intertidal \& upper sublittoral zone were collected.

14-Sasebo; 15-Omura Bay; 16-Iojima; 17-Nomo; 18-uncertain (Nagasaki); 19-Matsushima; 20-Oniike; 21-Tomioka; 22-off Tomioka; 23-Sakitsu; 24-Ushibuka; 25-off Ushibuka; 26uncertain (Amakusa); 27-Fukue; 28-Akune; 29-Kushikino; 30-Makurazaki; 31-Sakurajima; 32-off Sakurajima; 33-Shibushi Bay; 34-uncertain (Kagoshima); 35-Taira; 36-Iseki; 37Nishinoomote; 38-Yokino; 39-Sumiyoshi; 40-Miyanoura; 41-Shitogo; 48-Uka; 49-Kijoka; 50-Toguchi; 51-Sesoko; 52-Minatogawa; 53-Nakagushuku Bay; 54-Itanma; 55-Tamagusuku; 56-uncertain (Okinawa); 58-Ibaruma; 59-Kabira Bay; 60-Taketomi; 61-Kuroshima; 62Komi; 63-Haemi; 64-uncertain (Yaeyama). 
Table 1. Species occurrences at the localities in the intertidal \& upper sublittoral region. Species are shown by the species number given in the systematic list. Localities are shown by the station numbers and $a-b$ in Figs. 6-7. Sources of the data are shown in parentheses by capital letters which have been marked at the head of each specimen series in "Materials and methods". The data on the localities without parenthesis are based on my field surveys. Roman numerals indicate the data introduced from the following papers and informations: *I-Ohshima (1934); *II-Matsubayashi (1973); *III-Döderlein (1885); *IV-Yoshiwara (1901); *V-Tokioka (1953) in which species No. 87 was reported as Fibularia acuta; *VI-Hayasaka (1948) in which species Nos. 19 and 70 were reported each as Prionocidaris baculosa and Strongylocentrotus tuberculatus; *VII-oral informations.

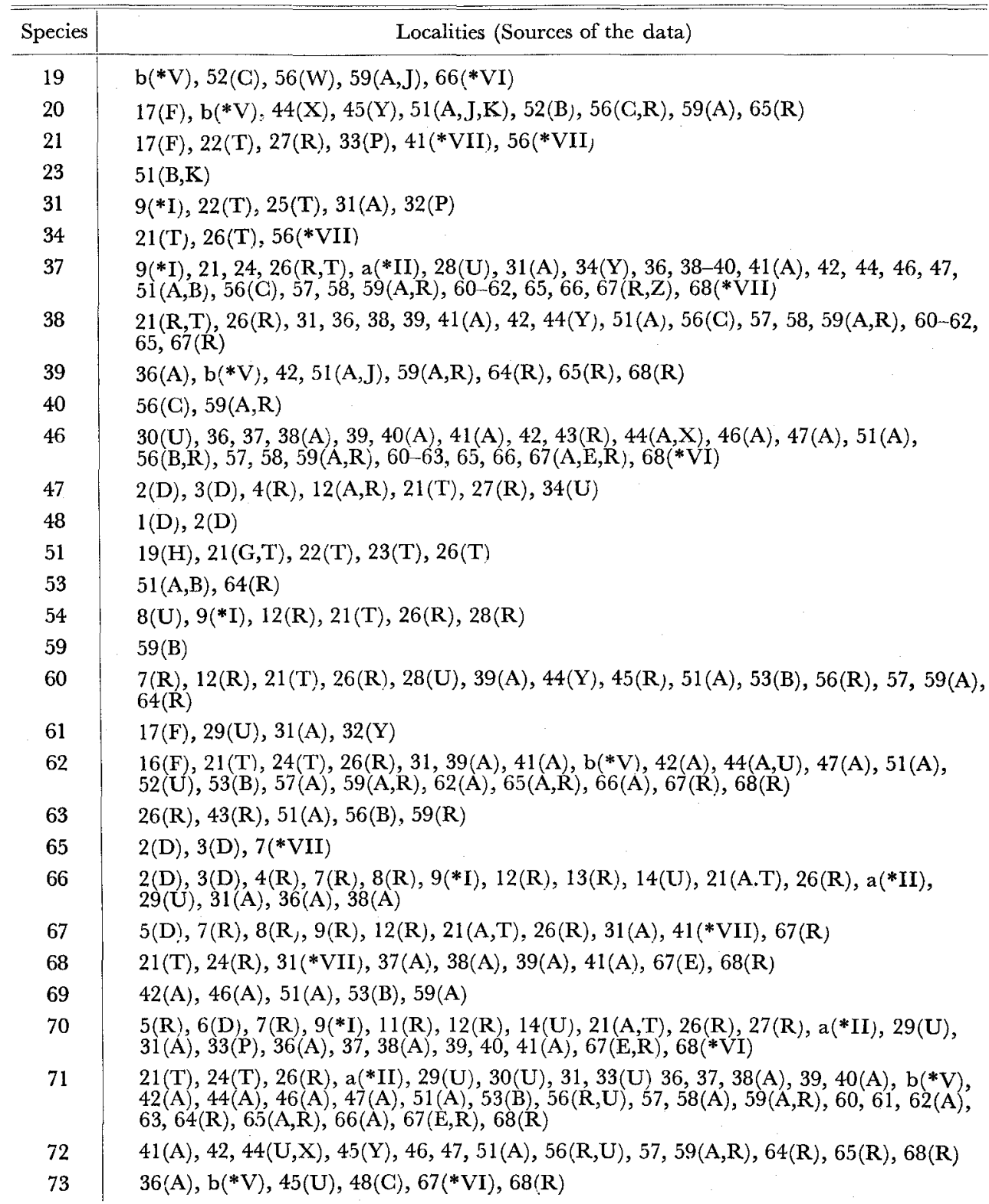


T'able 1. (continued)

\begin{tabular}{r|l}
\hline Species & \multicolumn{1}{|c}{ Localities (Sources of the data) } \\
\hline 74 & $26(\mathrm{R}), 28(\mathrm{R}), 51(\mathrm{~A}), 59(\mathrm{~A}), 64(\mathrm{R})$ \\
75 & $21(\mathrm{~T}), 24(\mathrm{R}), 41(\mathrm{~A}), \mathrm{b}(* \mathrm{~V}), 56(* \mathrm{VIII}), 59(\mathrm{R}), 67\left({ }^{*} \mathrm{IV}\right), 68(* \mathrm{VI})$ \\
82 & $7(\mathrm{R}), 21(\mathrm{~T}), 24(\mathrm{R}), 27(\mathrm{R}), \mathrm{a}\left({ }^{*} \mathrm{II}\right), 28(\mathrm{R}), 34(\mathrm{U}), 35(\mathrm{~N}), 37(\mathrm{~A}), 39(\mathrm{~A})$ \\
83 & $45(\mathrm{R})$ \\
85 & $68\left({ }^{*} \mathrm{VI}\right)$ \\
86 & $68(* \mathrm{VI})$ \\
87 & $\mathrm{~b}(* \mathrm{~V}), 59(\mathrm{I})$ \\
88 & $8(\mathrm{~N}), 21(\mathrm{~T})$ \\
89 & $8(\mathrm{~N}), 11(\mathrm{~T}), 21(\mathrm{~T}), 27(\mathrm{R})$ \\
93 & $43(\mathrm{R}), 50(\mathrm{~B}), 56(\mathrm{C}), 63(\mathrm{~A}), 64(\mathrm{R}), 67(* \mathrm{VI}), 68(* \mathrm{VI})$ \\
94 & $12(\mathrm{R}), 19(\mathrm{H}), 20(\mathrm{~T}), 26(\mathrm{R})$ \\
95 & $12(\mathrm{R})$ \\
97 & $2(\mathrm{D}), 3(\mathrm{D}), 12(\mathrm{R}), 23(\mathrm{~T}), 27(\mathrm{R}), 33(\mathrm{R})$ \\
98 & $68(* \mathrm{VI})$ \\
99 & $39(* \mathrm{IV}), 45(* \mathrm{IV}), 50(\mathrm{R}), 56(\mathrm{C})$ \\
100 & $11(\mathrm{R}), 12(\mathrm{R}), 15(\mathrm{R}), 26(\mathrm{R}), 44(\mathrm{Y})$ \\
107 & $2(\mathrm{D}), 3(\mathrm{D}), 21(\mathrm{R}), 28(\mathrm{R}), 32(\mathrm{~S}), 33(\mathrm{P})$ \\
108 & $59(\mathrm{~A}, \mathrm{R})$ \\
109 & $12(\mathrm{R}), 21(\mathrm{~T})$ \\
113 & $52(\mathrm{~B}), 56(\mathrm{C}), 59(\mathrm{~B}), 64(\mathrm{R})$ \\
114 & $7(\mathrm{R}), 10(\mathrm{R}), 21(\mathrm{~T}), 26(\mathrm{R}), 28(\mathrm{R})$ \\
115 & $64(\mathrm{R})$ \\
116 & $55(\mathrm{~B}), 56(\mathrm{C}), 64(\mathrm{R})$ \\
118 & $7(* \mathrm{VIII}), 11(\mathrm{R}), 22(* \mathrm{VII}), 67(* \mathrm{VI})$ \\
120 & $34(* \mathrm{III})$ \\
121 & $12(\mathrm{R}), 22(\mathrm{~T}), 27(\mathrm{R})$ \\
125 & $11(\mathrm{R}), 21(\mathrm{~T}), 33(\mathrm{P}), 40(\mathrm{~A})$ \\
\hline
\end{tabular}

(Kagoshima) (Fig. 8), however, there remains the possibility of their occurrences in area $\mathrm{I}$.

For the distribution of the tropical species, this line may be not very important. The tropical species tend to become gradually rare toward the north. The northern boundary of the distribution range of such species as Nos. 19, 87, 69 and 93 may be around this line or at the north of area $\mathrm{K}$ (the Amami Group), and that of such species as Nos. 23, 40, 53, 113 and 116 may be at the north of area L (the Okinawa

Figure 8. Geographical distributions of the intertidal \& upper sublittoral species. Species are shown by the species numbers given in the systematic list. Distribution area:

A-Korea Peninsula (southern part) (Sts. 1-4); B-Cheju Island (Sts. 5-6); CTsushima-Iki Group (Sts. 7-9); D-Northern Kyushu (Sts. 10-13); E-WesternSouthwestern Kyushu (Sts. 14-26) ; F-Goto Group (St. 27); G-Danjo Group (St. a); H-Southern Kyushu (Sts. 28-35); I-Ohsumi Group (Sts. 36-41); J-Tokara Group (St. b) ; K-Amami Group (Sts. 42-47); L-Okinawa Group (Sts. 48-56); M-Miyako Group (St. 57); N-Yaeyama Group (Sts. 58-66); O-Northern Taiwan (St. 67); P-Southern Taiwan (St. 68). 


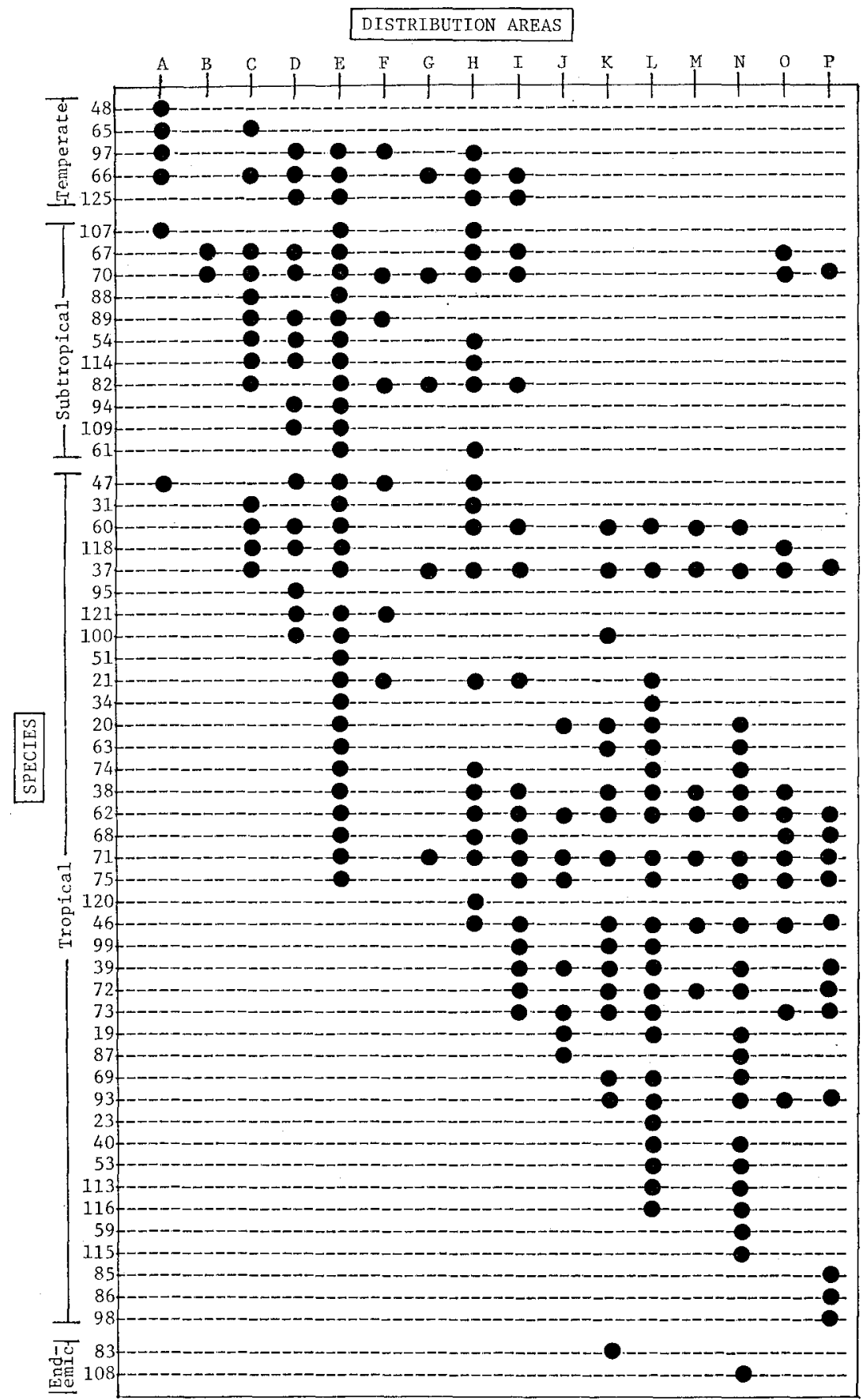

Fig. 8. 
Group) (Fig. 8). However, as many as twenty-five species (from No. 47 to No. 73 in Fig. 8) extend their distribution ranges to the north of this line.

Line 3 is drawn between area $\mathrm{N}$ (the Yaeyama Group) and area $\mathrm{O}$ (Taiwan):

Such subtropical species as Nos. 67 (Pseudocentrotus depressus) and 70 (Anthocidaris crassispina) found in Taiwan ${ }^{2}$ never occur in the areas from $\mathrm{J}$ (the Tokara Group) to $\mathrm{N}$ (the Yaeyama Group). The species of Echinostrephus found in areas $\mathrm{O}$ and $\mathrm{P}$ is No. 68 (E. aciculatus), while that found in area N is No. 69 (E. molaris). Nos. 853) (Clypeaster reticulatus), 86 (Arachnoides placenta) and 98 (Echinodiscus auritus) found in area $\mathbf{P}$ (southern Taiwan) are not found in the east of this line (Fig. 8). Line 3 may be drawn more exactly between Chi-lung and Yonaguni Island.

By the above three lines, the whole region can be divided into the following four zoogeographical subregions:

1. Southern Korea Subregion: This region includes the southern part of the Korea Peninsula and the adjacent, small islands.

2. Kyushu Subregion: The main area is around the coast of Kyushu (the main island). The region extends as far north as the Tsushima Group and Cheju Island, as west as the Goto and the Danjo Groups, and as far south as the Koshiki and the Ohsumi Groups (to Yaku Island).

3. Ryukyu Subregion: The main area is around the Amami, the Okinawa, and the Yaeyama Groups. The range extends from the Tokara Group westward to the Yaeyama Group (to Yonaguni Island).

4. Taiwan Subregion: The region includes the coast of Taiwan. This subregion may be divided further into the northwestern and the southeastern Taiwan subregions.

In order to examine the faunal composition of these subregions, the faunal elements found in each subregion were counted and their percentages were calculated. The result is shown in Table 2.

Table 2. Faunal composition in the four zoogeographical subregions established for the intertidal \& upper sublittoral region.

The numbers of species are parenthesized.

\begin{tabular}{l|r|r|r|r|r|r}
\hline Subregion & Temperate & Subtropical & Tropical & $\begin{array}{c}\text { Endemic } \\
\text { (uncertain) }\end{array}$ & Total \\
\hline Southern Korea & $66.7 \%(4)$ & $16.7 \%(1)$ & $16.7 \%(1)$ & $0.0 \%(0)$ & $100.0 \%(6)$ \\
Kyushu & $10.0 \%(4)$ & $27.5 \%(11)$ & $62.5 \%(25)$ & $0.0 \%(0)$ & $100.0 \%(40)$ \\
Ryukyu & $0.0 \%(0)$ & $0.0 \%(0)$ & $93.3 \%(28)$ & $6.7 \%(2)$ & $100.0 \%(30)$ \\
Taiwan & $0.0 \%(0)$ & $11.8 \%(2)$ & $88.2 \%(15)$ & $0.0 \%(0)$ & $100.0 \%(17)$ \\
The whole region & $8.8 \%(5)$ & $19.3 \%(11)$ & $68.4 \%(39)$ & $3.5 \%(2)$ & $100.0 \%(57)$ \\
\hline
\end{tabular}

2) The record of No. 67 in Taiwan was based on only a single specimen which had been collected at Chi-lung and was preserved at Kyushu University. No. 70 was commonly found at the shore of Chi-lung during my survey in 1975.

3) No. 85 is an ubiquitous species. Probably it will be found in the Yaeyama or the Okinawa Group in the future. 
From Table 2, the characteristics of the fauna of each subregion are summarized as follows:

Southern Korea Subregion: Temperate elements dominate. Subtropical and tropical elements are rare.

Kyushu Subregion: Tropical elements dominate, however, the occurrences of a considerable number of subtropical elements together with a few temperate elements are notable.

Ryukyu Subregion: The fauna is completely tropical. Temperate and subtropical elements are absent.

Taiwan Subregion: Tropical elements dominate. A few subtropical elements occur. Temperate elements are absent.

\section{The Lower Sublittoral Fauna}

The localities where the specimens from the lower sublittoral zone were collected are shown in maps (Figs. 9-10) and in a table (Tab. 3).

The result of the specimen examination is shown as a table (Tab. 4).

The data in Table 4 were rearranged for the faunal analysis, and are shown as a figure of regional distributions of the lower sublittoral species (Fig. 11).

In order to examine the faunal composition of the areas in Figure 11, the faunal elements found in each area were counted and their percentages were calculated. The result is shown in Table 5 .

It is suggested from Table 5 that the composition of the fauna of each area is not markedly different from each other, except that of the submarine banks, where a fairly high percentage of tropical element $(77.8 \%$ ) and a low percentage of subtropical element $(22.2 \%)$ were found. It is also noteworthy that the temperate element is absent from the submarine banks and SE.-S. continental shelf.

For the comparison of the faunal relationship between these areas, the NomuraSimpson's Coefficient (Nomura, 1939, 1940; Simpson, 1943; Kimoto, 1967) was used as an indication of the degree of relatedness of the fauna between two areas. It is calculated from Figure 11 by dividing the number of common species between two areas by the smaller number of species occurring in two areas. The result is shown in Table 6.

Roughly speaking, the values are not low throughout the table except those concerned with the submarine banks. It means that the faunas of the lower sublittoral zone are more or less closely related with each other except that of the submarine banks.

Considerablly high values are seen among the continental shelf areas and S. Kyushu shelf as follows:

N.-m.-NE. continental shelf \& S. Kyushu shelf......................0.706

N.-m.-NE. continental shelf \& SE.-S. continental shelf.................. 0.647

SE.-S. continental shelf \& S. Kyushu shelf...........................600 


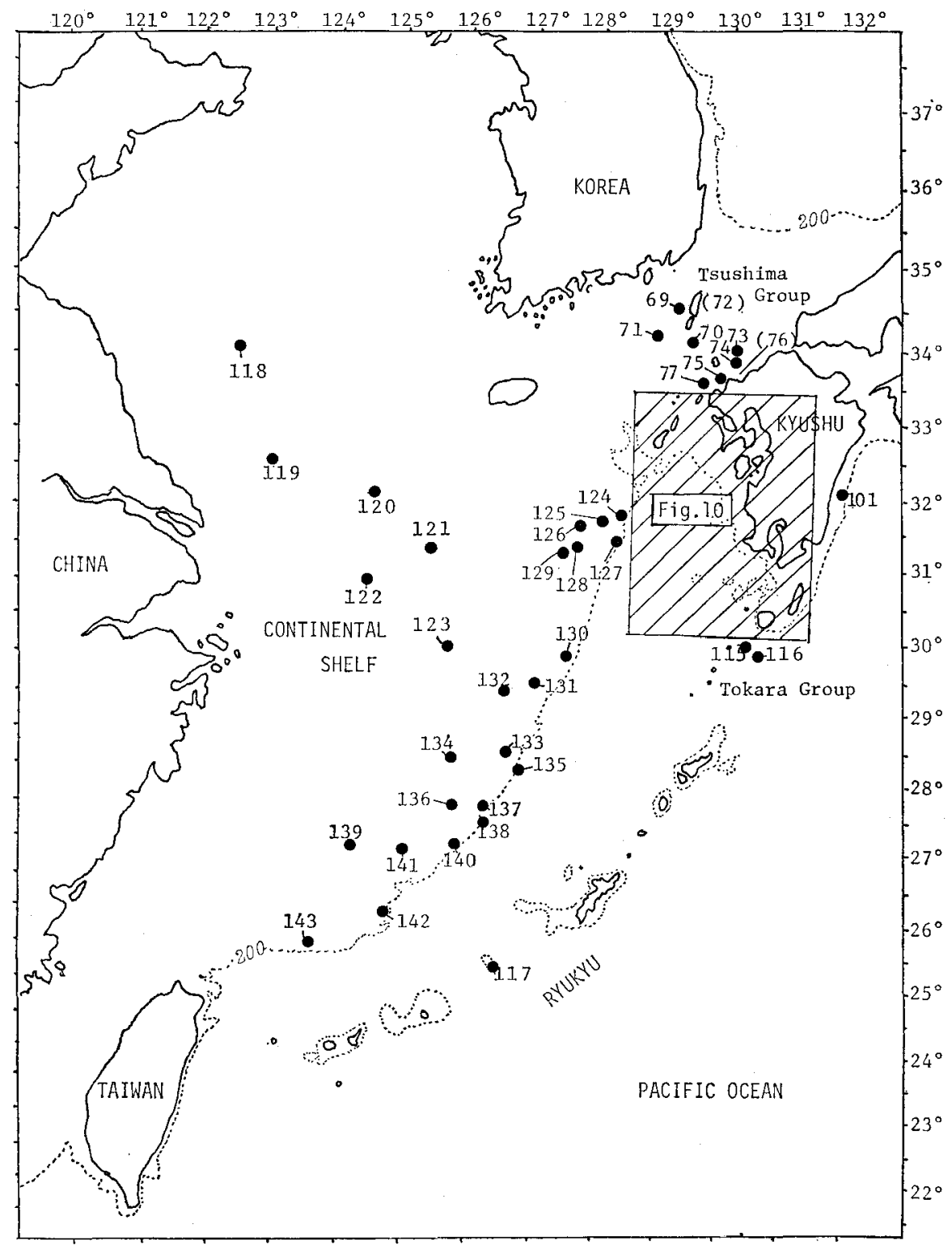

Figure 9. A map of the whole region showing the locations where the specimens from the lower sublittoral zone were collected. Data on each station are in Table 3. 


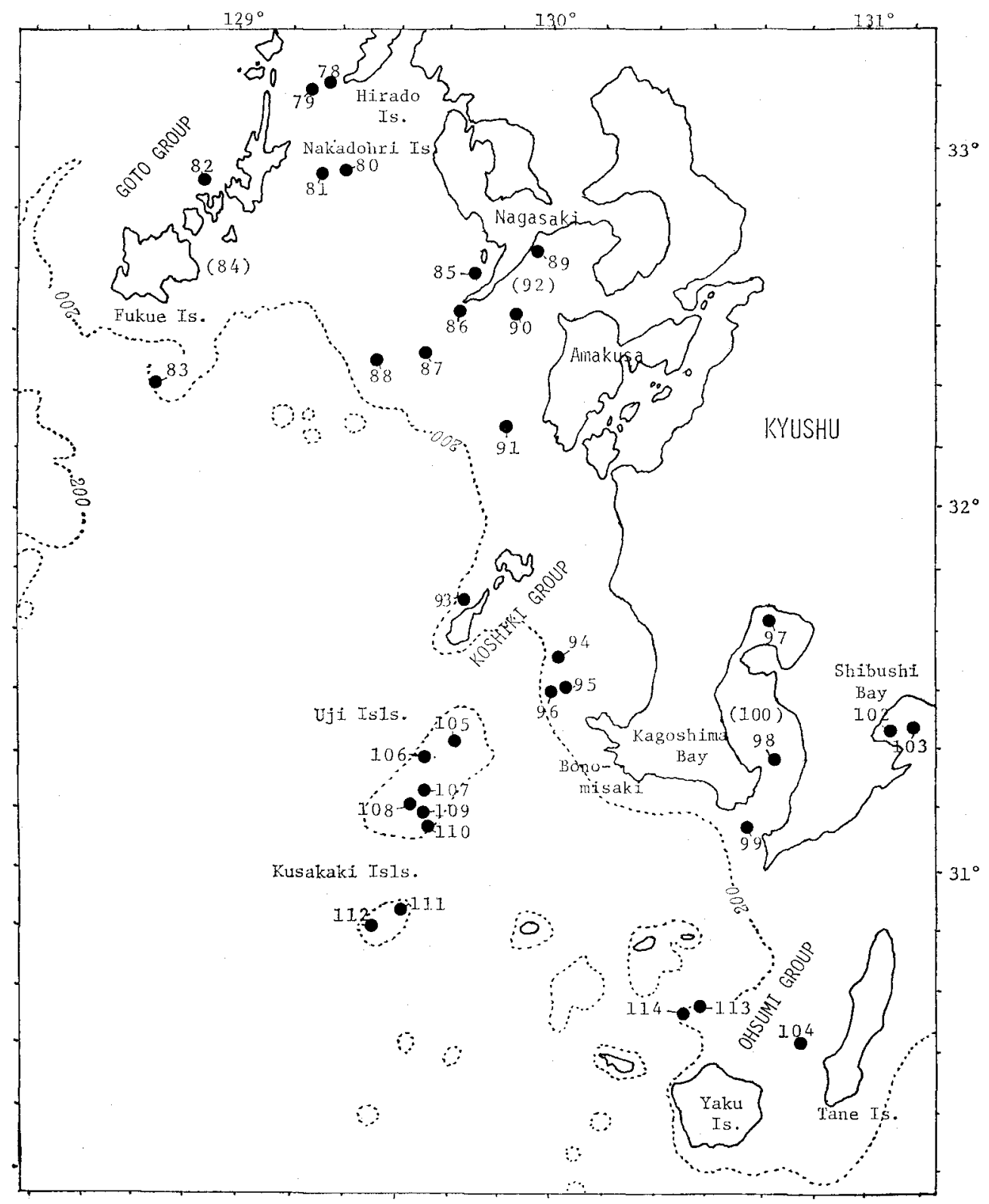

Figure 10. An enlarged map of southwestern Kyushu showing the locations where the specimens from the lower sublittoral zone were collected. Data on each station are in Table 3. 
Table 3. The data on localities and depths of the stations in Figs. 9-10.

\begin{tabular}{|c|c|c|c|c|}
\hline $\begin{array}{l}\text { Station } \\
\text { Number }\end{array}$ & Locality & $\begin{array}{c}\text { Latitude } \\
\text { N. }\end{array}$ & $\begin{array}{c}\text { Longitude } \\
\text { E. }\end{array}$ & $\begin{array}{l}\text { Depth } \\
\text { (m) }\end{array}$ \\
\hline 69 & W. of Tsushima Isls. & $34^{\circ} 25.3^{\prime}$ & $129^{\circ} 05.4^{\prime}$ & 150 \\
\hline 70 & S. of Tsushima Isls. & $34^{\circ} 00.7^{\prime}$ & $129^{\circ} 19.4^{\prime}$ & 110 \\
\hline 71 & S. of Tsushima Isls. & $33^{\circ} 59.4^{\prime}$ & $128^{\circ} 48.0^{\prime}$ & 102 \\
\hline 72 & off Tsushima Isls.L & \multicolumn{2}{|c|}{ uncertain } & uncertain \\
\hline 73 & E. of Iki Isl. & $33^{\circ} 51.9^{\prime}$ & $130^{\circ} 00.1^{\prime}$ & 51 \\
\hline 74 & E. of Iki Isl. & $33^{\circ} 45.1^{\prime}$ & $129^{\circ} 57.5^{\prime}$ & 45 \\
\hline 75 & S. of Iki. Isl. & $33^{\circ} 30.5^{\prime}$ & $129^{\circ} 47.5^{\prime}$ & 38 \\
\hline 76 & off Fukuoka & \multicolumn{2}{|c|}{ uncertain } & uncertain \\
\hline 77 & N. of Hirado Isl. & $33^{\circ} 25.6^{\prime}$ & $129^{\circ} 28.3^{\prime}$ & $6 \mathrm{I}$ \\
\hline 78 & S. of Hirado Isl. & $33^{\circ} 09.4^{\prime}$ & $129^{\circ} 18.6^{\prime}$ & 83 \\
\hline 79 & S. of Hirado Isl. & $33^{\circ} 08.2^{\prime}$ & $129^{\circ} 16.3^{\prime}$ & 56 \\
\hline 80 & E. of Nakadohri Isl. & $32^{\circ} 55.0^{\prime}$ & $129^{\circ} 20.5^{\prime}$ & 56 \\
\hline 81 & E. of Nakadohri Isl. & $32^{\circ} 54.7^{\prime}$ & $129^{\circ} 15.2^{\prime}$ & 49 \\
\hline 82 & W. of Nakadohri Isl. & $32^{\circ} 54.0^{\prime}$ & $128^{\circ} 53.8^{\prime}$ & 82 \\
\hline 83 & S. of Fukue Isl. & $32^{\circ} 21.5^{\prime}$ & $128^{\circ} 46: 2^{\prime}$ & 180 \\
\hline 84 & off Goto Group & \multicolumn{2}{|c|}{ uncertain } & uncertain \\
\hline 85 & W. of Nagasaki & $32^{\circ} 40.4^{\prime}$ & $129^{\circ} 46.5^{\prime}$ & 58 \\
\hline 86 & off Nomo & \multicolumn{2}{|c|}{ uncertain } & uncertain \\
\hline 87 & S.W. of Nagasaki & $32^{\circ} 26.8^{\prime}$ & $129^{\circ} 34.0^{\prime}$ & 96 \\
\hline 88 & S.W. of Nagasaki & $32^{\circ} 24.8^{\prime}$ & $129^{\circ} 24.7^{\prime}$ & 173 \\
\hline 89 & E. of Nagasaki & $32^{\circ} 42.0^{\prime}$ & $129^{\circ} 57.6^{\prime}$ & 44 \\
\hline 90 & W. of Amakusa & $32^{\circ} 31.2^{\prime}$ & $129^{\circ} 53.5^{\prime}$ & 77 \\
\hline 91 & W. of Amakusa & $32^{\circ} 12.2^{\prime}$ & $129^{\circ} 50.2^{\prime}$ & 106 \\
\hline 92 & off Tomioka & \multicolumn{2}{|c|}{ uncertain } & uncertain \\
\hline 93 & W. of Koshiki Group & $31^{\circ} 44.2^{\prime}$ & $129^{\circ} 42.4^{\prime}$ & 150 \\
\hline 94 & S.E. of Koshiki Group & $31^{\circ} 35^{\prime}$ & $130^{\circ} 00^{\prime}$ & 150 \\
\hline 95 & S.E. of Koshiki Group & $31^{\circ} 30^{\prime}$ & $130^{\circ} 00^{\prime}$ & $150-200$ \\
\hline 96 & S.E. of Koshiki Group & $31^{\circ} 29.2^{\prime}$ & $130^{\circ} 01.5^{\prime}$ & 196 \\
\hline 97 & Kagoshima Bay & $31^{\circ} 40.2^{\prime}$ & $130^{\circ} 40.3^{\prime}$ & 145 \\
\hline 98 & Kagoshima Bay & $31^{\circ} 17^{\prime}$ & $130^{\circ} 42^{\prime}$ & 126 \\
\hline 99 & Kagoshima Bay & $31^{\circ} 05^{\prime}$ & $130^{\circ} 35^{\prime}$ & $150-200$ \\
\hline 100 & Kagoshima Bay & \multicolumn{2}{|c|}{ uncertain } & uncertain \\
\hline 101 & N.W. of Miyazaki & $32^{\circ} 00.3^{\prime}$ & $131^{\circ} 37.2^{\prime}$ & 48 \\
\hline 102 & Shibushi Bay & $31^{\circ} 23^{\prime}-25^{\prime}$ & $131^{\circ} 04^{\prime}-12^{\prime}$ & 50 \\
\hline 103 & Shibushi Bay & \multicolumn{2}{|c|}{ uncertain } & uncertain \\
\hline 104 & W. of Tane Isl. & $30^{\circ} 31.0^{\prime}$ & $130^{\circ} 48.5^{\prime}$ & $52-54$ \\
\hline 105 & around Uji Isls. & $31^{\circ} 21.7^{\prime}$ & $129^{\circ} 41.6^{\prime}$ & 119 \\
\hline 106 & around Uji Isls. & $31^{\circ} 20.2^{\prime}$ & $129^{\circ} 35.3^{\prime}$ & 120 \\
\hline
\end{tabular}


Table 3. (continued)

\begin{tabular}{|c|c|c|c|c|}
\hline $\begin{array}{c}\text { Station } \\
\text { Number }\end{array}$ & Locality & $\begin{array}{l}\text { Latitude } \\
\text { N. }\end{array}$ & $\begin{array}{c}\text { Longitude } \\
\text { E. }\end{array}$ & $\underset{(\mathrm{m})}{\text { Depth }}$ \\
\hline 107 & around Uji Isls. & $31^{\circ} 13.2^{\prime}$ & $129^{\circ} 35.8^{\prime}$ & 150 \\
\hline 108 & around $\mathrm{Uji}_{\mathrm{j}}$ Isls. & $31^{\circ} 12.2^{\prime}$ & $129^{\circ} 31.8^{\prime}$ & 120 \\
\hline 109 & around $\mathrm{Uji}$ Isls. & $31^{\circ} 11.1^{\prime}$ & $129^{\circ} 34.3^{\prime}$ & 136 \\
\hline 110 & around Uji Isls. & $31^{\circ} 07.8^{\prime}$ & $129^{\circ} 32.3^{\prime}$ & 140 \\
\hline 111 & around Kusakaki Isls. & $30^{\circ} 53.1^{\prime}$ & $129^{\circ} 30.5^{\prime}$ & $190-200$ \\
\hline 112 & around Kusakaki Isls. & $30^{\circ} 50.4^{\prime}$ & $129^{\circ} 24.4^{\prime}$ & $150-158$ \\
\hline 113 & N. of Yaku Isls. & $30^{\circ} 37.9^{\prime}$ & $130^{\circ} 29.0^{\prime}$ & 210 \\
\hline 114 & N. of Yaku Isls. & $30^{\circ} 36.1^{\prime}$ & $130^{\circ} 26.2^{\prime}$ & $152-158$ \\
\hline 115 & Tokara Strait & $30^{\circ} 05.1^{\prime}$ & $130^{\circ} 05.1^{\prime}$ & $90-120$ \\
\hline 116 & Tokara Strait & $29^{\circ} 48.4^{\prime}$ & $130^{\circ} 11.4^{\prime}$ & $160-210$ \\
\hline 117 & N.E. of Miyako Isl. & $25^{\circ} 33^{\prime}-34^{\prime}$ & $126^{\circ} 03^{\prime}-04^{\prime}$ & 210 \\
\hline 118 & N.W. Cont. Shelf & $33^{\circ} 35.3^{\prime}$ & $122^{\circ} 27.0^{\prime}$ & 32 \\
\hline 119 & N.W. Cont. Shelf & $32^{\circ} 30.2^{\prime}$ & $123^{\circ} 02.0^{\prime}$ & 34 \\
\hline 120 & m. Cont. Shelf. & $32^{\circ} 06.1^{\prime}$ & $124^{\circ} 34.9^{\prime}$ & 43 \\
\hline 121 & m. Cont. Shelf. & $31^{\circ} 18.5^{\prime}$ & $125^{\circ} 19.2^{\prime}$ & 59 \\
\hline 122 & m. Cont. Shelf. & $31^{\circ} 00.0^{\prime}$ & $124^{\circ} 21.4^{\prime}$ & 45 \\
\hline 123 & m. Cont. Shelf. & $30^{\circ} 00.0^{\prime}$ & $125^{\circ} 29.5^{\prime}$ & 57 \\
\hline 124 & N.E. Cont. Shelf & $31^{\circ} 46.6^{\prime}$ & $128^{\circ} 09.0^{\prime}$ & 154 \\
\hline 125 & N.E. Cont. Shelf & $31^{\circ} 38.5^{\prime}$ & $127^{\circ} 55.2^{\prime}$ & 143 \\
\hline 126 & N.E. Cont. Shelf & $31^{\circ} 35^{\prime}$ & $127^{\circ} 35^{\prime}$ & 100 \\
\hline 127 & N.E. Cont. Shelf & $31^{\circ} 24.0^{\prime}-24.9^{\prime}$ & $\begin{array}{r}128^{\circ} 07.6^{\prime} \\
-09.1^{\prime}\end{array}$ & 150 \\
\hline 128 & N.E. Cont. Shelf & $31^{\circ} 19.5^{\prime}$ & $127^{\circ} 32.0^{\prime}$ & 126 \\
\hline 129 & N.E. Cont. Shelf & $31^{\circ} 15.5^{\prime}$ & $127^{\circ} 17.0^{\prime}$ & 120 \\
\hline 130 & S.E. Cont. Shelf & $29^{\circ} 47.0^{\prime}$ & $127^{\circ} 30.0^{\prime}$ & $160-180$ \\
\hline 131 & S.E. Cont. Shelf & $29^{\circ} 28^{\prime}-30^{\prime}$ & $127^{\circ} 12^{\prime}-16^{\prime}$ & $125-133$ \\
\hline 132 & S.E. Cont. Shelf & $29^{\circ} 23.2^{\prime}-23.7^{\prime}$ & $\begin{array}{r}126^{\circ} 29.2^{\prime} \\
-29.5^{\prime}\end{array}$ & 97 \\
\hline 133 & S.E. Cont. Shelf & $28^{\circ} 32.0^{\prime}$ & $126^{\circ} 18.8^{\prime}$ & 115 \\
\hline 134 & S.E. Cont. Shelf & $28^{\circ} 32.0^{\prime}$ & $125^{\circ} 34.0^{\prime}$ & 101 \\
\hline 135 & S.E. Cont. Shelf & $28^{\circ} 12^{\prime}-13^{\prime}$ & $126^{\circ} 55^{\prime}-56^{\prime}$ & $160-165$ \\
\hline 136 & S.E. Cont. Shelf & $27^{\circ} 52.6^{\prime}$ & $125^{\circ} 34.8^{\prime}$ & 109 \\
\hline 137 & S.E. Cont. Shelf & $27^{\circ} 42^{\prime}-45^{\prime}$ & $126^{\circ} 06^{\prime}-08^{\prime}$ & 125 \\
\hline 138 & S.E. Cont. Shelf & $27^{\circ} 33.9^{\prime}$ & $126^{\circ} 00.8^{\prime}$ & 135 \\
\hline 139 & S.E. Cont. Shelf & $27^{\circ} 17.5^{\prime}$ & $124^{\circ} 00.0^{\prime}$ & 99 \\
\hline 140 & S.E. Cont. Shelf & $27^{\circ} 16.0^{\prime}$ & $125^{\circ} 34.5^{\prime}$ & $115-118$ \\
\hline 141 & S.E. Cont. Shelf & $27^{\circ} 14.5^{\prime}$ & $124^{\circ} 45.0^{\prime}$ & 98 \\
\hline 142 & S. Cont. Shelf & $26^{\circ} 15.7^{\prime}-18.3^{\prime}$ & $\begin{array}{r}124^{\circ} 30.0^{\prime} \\
-32.8^{\prime}\end{array}$ & $165-187$ \\
\hline 143 & S. Cont. Shelf & $25^{\circ} 47.7^{\prime}-48.3^{\prime}$ & $\begin{array}{r}123^{\circ} 47.5^{\prime} \\
-51.6^{\prime}\end{array}$ & 130 \\
\hline
\end{tabular}


Table 4. Species occurrences at the localities in the lower sublittoral region.

As for the symbols, refer to Tab. 1.

*I-Korea Strait (Mortensen, 1928a) *II-off Kagoshima Bay (A. Agassiz and H.L. Clark, 1907b; Mortensen, 1928a)

*III-off Kagoshima Bay, 185-274 m (A. Agassiz and H.L. Clark, 1907b)

*IV-S.W. of the Tsushima Group $\left(33^{\circ} 41^{\prime} \mathrm{N}, 128^{\circ} 50^{\prime} \mathrm{E}\right), 135 \mathrm{~m}$ (Mortensen, 1935)

*V-S.W. of the Goto Group, 170-190 m (A. Agassiz and H.L. Clark, 1907b)

*VI-Korea Strait, $106 \mathrm{~m}$ (A. Agassiz and H.L. Clark, 1907b)

*VII-Tsushima Strait (Mortensen, 1948d)

*VIII-near Amami-Ohshima Island (Döderlein, 1885)

*IX-?southeastern part of the continental shelf

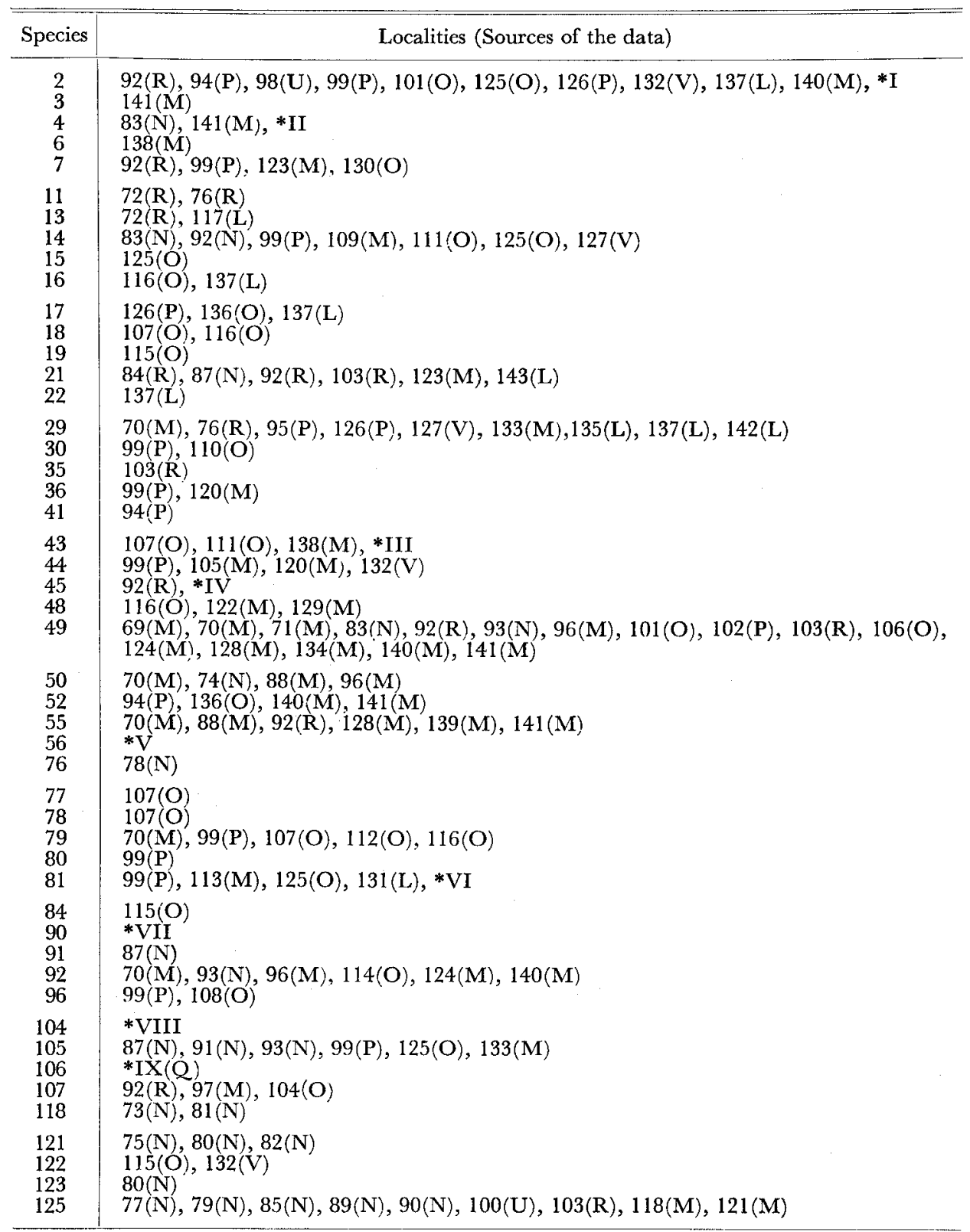




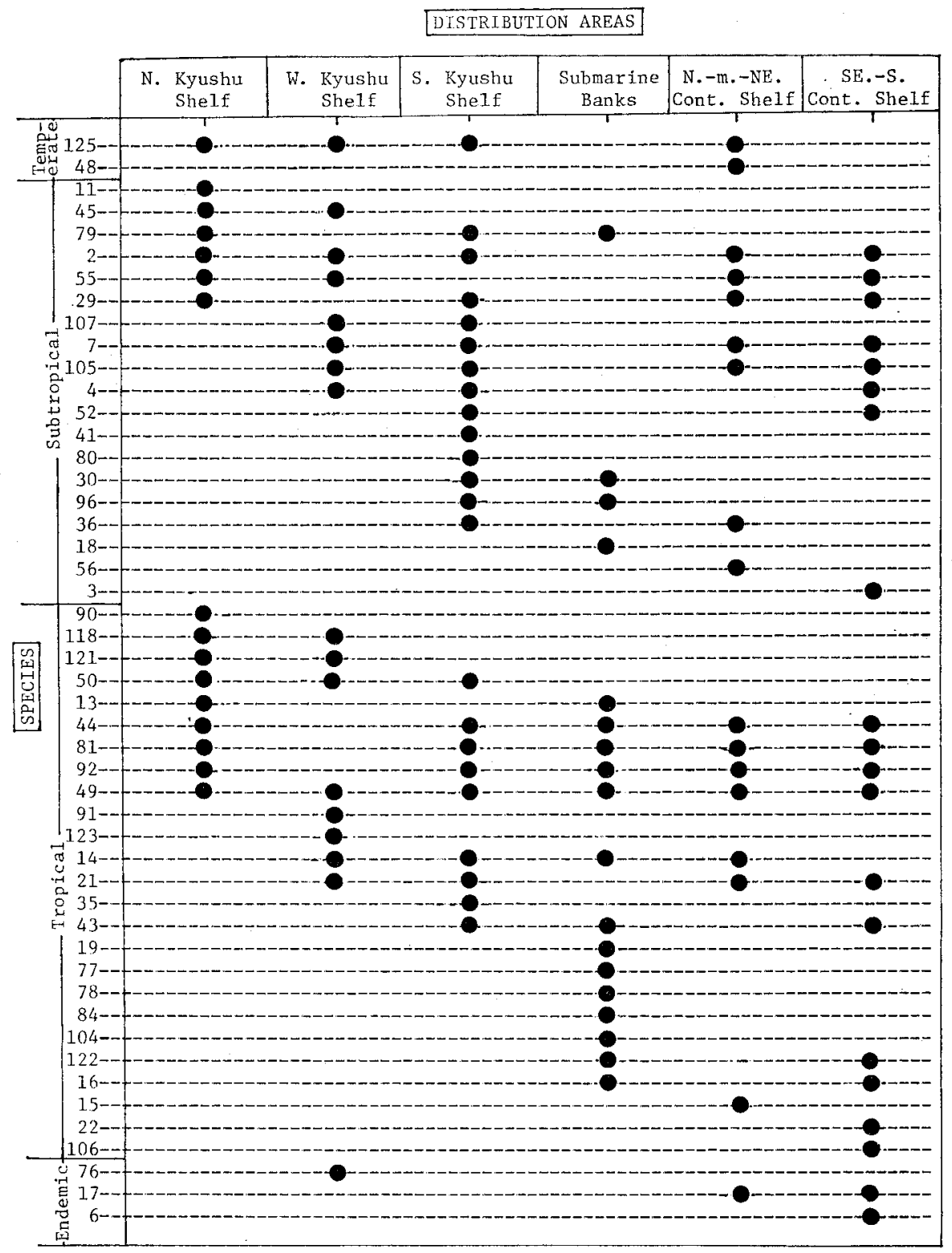

Figure 11. Regional distributions of the lower sublittoral species. Species are shown by the species numbers given in the systematic list.

N. Kyushu Shelf, Sts. 69-77; W. Kyushu Shelf, Sts. 78-92; S. Kyushu Shelf, Sts. 93-104; Submarine Banks, Sts. 105-117; N.-m.-NE. Cont. Shelf, Sts. 118-129; SE.-S. Cont. Shelf, Sts. 130-143. 
- Table 5. Faunal composition in the areas of the lower sublittoral region. The numbers of species are parenthesized.

\begin{tabular}{l|r|r|r|r|r|}
\hline \multicolumn{1}{c|}{ Element } & Temperate & Subtropical & Tropical & $\begin{array}{c}\text { Endemic } \\
\text { (uncertain) }\end{array}$ & Total \\
\hline N. Kyushu Shelf & $6.3 \%(1)$ & $37.5 \%(6)$ & $56.3 \%(9)$ & $0.0 \%(0)$ & $100.0 \%(16)$ \\
W. Kyushu Shelf & $5.9 \%(1)$ & $41.2 \%(7)$ & $47.1 \%(8)$ & $5.9 \%(1)$ & $100.0 \%(17)$ \\
S. Kyushu Shelf & $4.3 \%(1)$ & $56.5 \%(13)$ & $39.1 \%(9)$ & $0.0 \%(0)$ & $100.0 \%(23)$ \\
Submarine Banks & $0.0 \%(0)$ & $22.2 \%(4)$ & $77.8 \%(14)$ & $0.0 \%(0)$ & $100.0 \%(18)$ \\
N.-m.-NE. Cont. Shelf & $11.8 \%(2)$ & $41.2 \%(7)$ & $41.2 \%(7)$ & $5.9 \%(1)$ & $100.0 \%(17)$ \\
SE.-S. Cont. Shelf & $0.0 \%(0)$ & $40.0 \%(8)$ & $50.0 \%(10)$ & $10.0 \%(2)$ & $100.0 \%(20)$ \\
The whole area & $4.1 \%(2)$ & $38.8 \%(19)$ & $51.0 \%(25)$ & $6.1 \%(3)$ & $100.0 \%(49)$ \\
\hline
\end{tabular}

Table 6. Nomura-Simpson's Coefficient between the areas in the lower sublittoral region. The numbers of common species between two areas are parenthesized.

\begin{tabular}{|c|c|c|c|c|c|}
\hline & N. Kyushu & & & & \\
\hline $\begin{array}{l}\text { W. Kyushu } \\
\text { Shelf }\end{array}$ & $0.500(8)$ & $\begin{array}{l}\text { W. Kyushu } \\
\text { Shelf }\end{array}$ & & & \\
\hline $\begin{array}{l}\text { S. Kyushu } \\
\text { Shelf }\end{array}$ & $0.563(9)$ & $0.588(10)$ & $\begin{array}{l}\text { S. Kyushu } \\
\text { Shelf }\end{array}$ & & \\
\hline $\begin{array}{c}\text { Submarine } \\
\text { Banks }\end{array}$ & $0.375(6)$ & $0.118(2)$ & $0.500(9)$ & $\begin{array}{c}\text { Submarine } \\
\text { Banks }\end{array}$ & \\
\hline $\begin{array}{l}\text { N.-m.-NE. } \\
\text { Cont. Shelf }\end{array}$ & $0.500(8)$ & $0.471(8)$ & $0.706(12)$ & $0.294(5)$ & $\begin{array}{l}\text { N.-m.-NE. } \\
\text { Cont. Sheli. }\end{array}$ \\
\hline $\begin{array}{l}\text { SE.-S. } \\
\text { Cont. Shelf }\end{array}$ & $0.438(7)$ & $0.353(6)$ & $0.600(12)$ & $0.389(7)$ & $0.647(11)$ \\
\hline
\end{tabular}

Markedly low values which indicate the distant relationship are seen in the following areas:

Submarine banks \& W. Kyushu shelf.

Submarine banks \& N.-m.-NE. continental shelf.

W. Kyushu shelf \& SE.-S. continental shelf.

Submarine banks \& N. Kyushu shelf.

Submarine banks \& SE.-S. continental shelf.

\section{The Bathyal Fauna}

The localities where the specimens from the bathyal zone were collected are shown in a map (Fig. 12) and in a table (Tab. 7).

The result of the specimen examination is shown as a table (Tab. 8).

Based on the data in Table 8 , the vertical and the regional distributions of the bathyal species are shown as a figure (Fig. 13).

From Figure 13, the ratio of the Japanese (excluding the endemic; Nos. 1, 33, 129 in Fig. 13) and the ubiquitous elements within each vertical zone are counted as follows: 


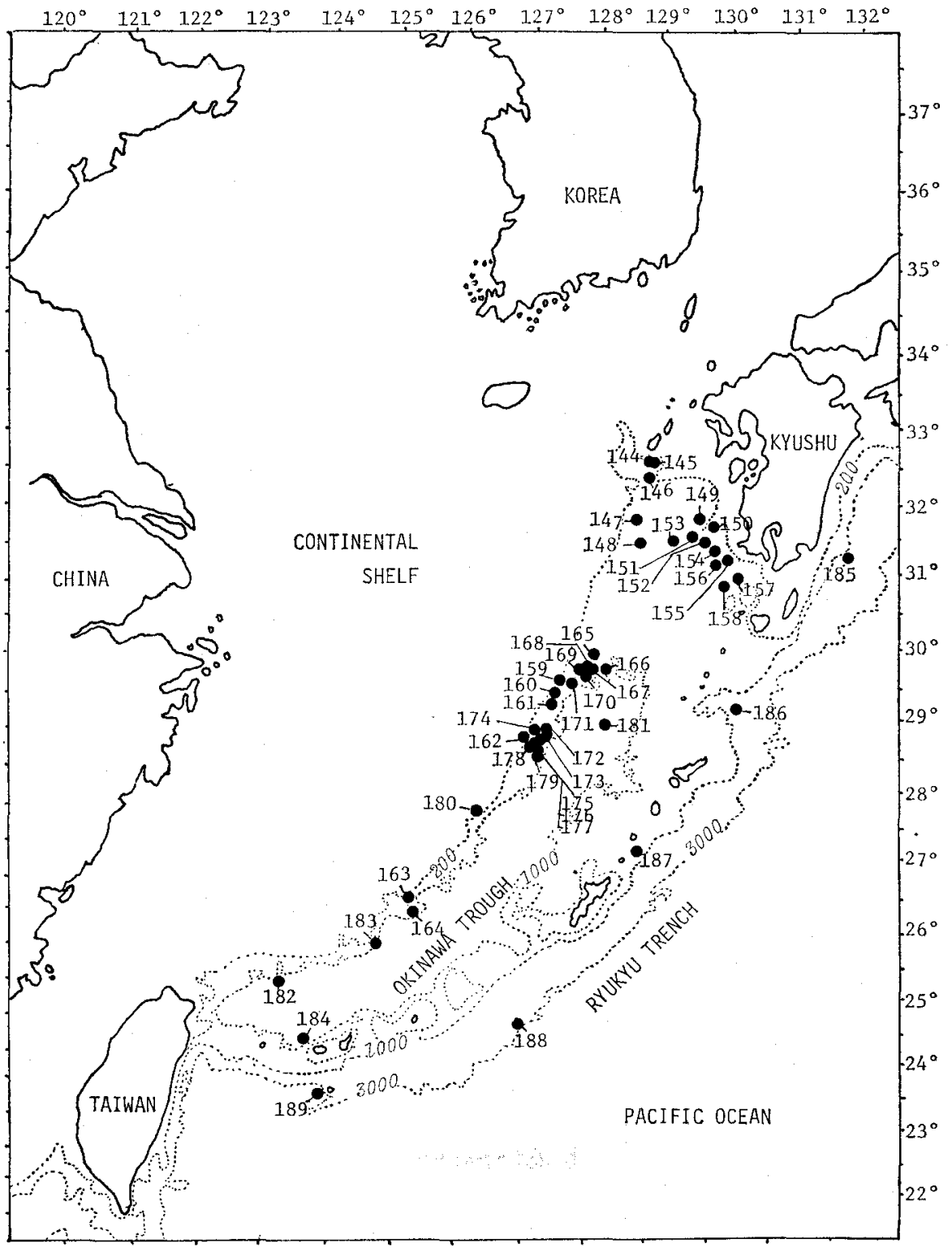

Figure 12. A map of the whole region showing the locations where the specimens from the bathyal zone were collected. Data on each station are in Table 7. 
Table 7. The data on localities and depths of the stations in Fig. 12.

\begin{tabular}{|c|c|c|c|c|}
\hline $\begin{array}{l}\text { Station } \\
\text { Number }\end{array}$ & Locality & $\begin{array}{c}\text { Latitude } \\
\text { N. }\end{array}$ & $\begin{array}{c}\text { Longitude } \\
\text { E. }\end{array}$ & $\underset{(\mathrm{m})}{\text { Depth }}$ \\
\hline 144 & S. of Fukue Isl. & $32^{\circ} 25.5^{\prime}$ & $128^{\circ} 42.7^{\prime}$ & 230 \\
\hline 145 & S. of Fukue Isl. & $32^{\circ} 25.5^{\prime}$ & $128^{\circ} 42.7^{\prime}$ & 238 \\
\hline 146 & S. of Fukue Isl. & $32^{\circ} 11.4^{\prime}$ & $128^{\circ} 44.9^{\prime}$ & 318 \\
\hline 147 & S.E. of Danjo Isls. & $31^{\circ} 38.0^{\prime}$ & $128^{\circ} 28.0^{\prime}$ & 470 \\
\hline 148 & S.E. of Danjo Isls. & $31^{\circ} 18.3^{\prime}$ & $128^{\circ} 35.4^{\prime}$ & $460-512$ \\
\hline 149 & W. of Koshiki Isls. & $31^{\circ} 44.1^{\prime}$ & $129^{\circ} 41.5^{\prime}$ & 280 \\
\hline 150 & E. of Koshiki Isls. & $31^{\circ} 39^{\prime}$ & $129^{\circ} 51^{\prime}$ & 350 \\
\hline 151 & S. of Koshiki Isls. & $31^{\circ} 35^{\prime}$ & $129^{\circ} 42^{\prime}$ & 380 \\
\hline 152 & S. of Koshiki Isls. & $31^{\circ} 31.9^{\prime}$ & $129^{\circ} 47.9^{\prime}$ & 580 \\
\hline 153 & S.W. of Koshiki Isls. & $31^{\circ} 31.0^{\prime}$ & $129^{\circ} 21.0^{\prime}$ & $730-740$ \\
\hline 154 & W. of Bono-misaki & $31^{\circ} 18.1^{\prime}$ & $129^{\circ} 53.4^{\prime}$ & 310 \\
\hline 155 & W. of Bono-misaki & $31^{\circ} 13.6^{\prime}$ & $129^{\circ} 58.4^{\prime}$ & $295-300$ \\
\hline 156 & W. of Bono-misaki & $31^{\circ} 09^{\prime}$ & $129^{\circ} 51^{\prime}$ & 350 \\
\hline 157 & S.W. of Bono-misaki & $30^{\circ} 53.4^{\prime}$ & $130^{\circ} 07.0^{\prime}$ & 372 \\
\hline 158 & S.W. of Bono-misaki & $30^{\circ} 44.6^{\prime}$ & $129^{\circ} 55.3^{\prime}$ & 425 \\
\hline 159 & S.E. Cont. slope & $29^{\circ} 25.4^{\prime}-27.3^{\prime}$ & $127^{\circ} 19.6^{\prime}-21.1^{\prime}$ & $208-210$ \\
\hline 160 & S.E. Cont. slope & $29^{\circ} 19^{\prime}$ & $127^{\circ} 19^{\prime}$ & $255-260$ \\
\hline 161 & S.E. Cont. slope & $29^{\circ} 11^{\prime}-16^{\prime}$ & $127^{\circ} 11^{\prime}-17^{\prime}$ & $300-310$ \\
\hline 162 & S.E. Cont. slope & $28^{\circ} 37.0^{\prime}$ & $126^{\circ} 56.0^{\prime}$ & $285-430$ \\
\hline 163 & S. Cont. slope & $26^{\circ} 33.2^{\prime}-34.4^{\prime}$ & $125^{\circ} 04.9^{\prime}-05.9^{\prime}$ & $260-280$ \\
\hline 164 & S. Cont. slope & $26^{\circ} 21.0^{\prime}-23.3^{\prime}$ & $125^{\circ} 04.0^{\prime}-00.7^{\prime}$ & $295-385$ \\
\hline 165 & N.-W. Okinawa Trough & $29^{\circ} 57^{\prime}-58^{\prime}$ & $128^{\circ} 00^{\prime}-02^{\prime}$ & $585-615$ \\
\hline 166 & N.-W. Okinawa Trough & $29^{\circ} 43.8^{\prime}-47.1^{\prime}$ & $128^{\circ} 26.8^{\prime}-27.1^{\prime}$ & $990-1,050$ \\
\hline 167 & N.-W. Okinawa Trough & $29^{\circ} 44^{\prime}$ & $128^{\circ} 03^{\prime}$ & 815 \\
\hline 168 & N.-W. Okinawa Trough & $29^{\circ} 44^{\prime}-46^{\prime}$ & $127^{\circ} 57^{\prime}-59^{\prime}$ & $710-713$ \\
\hline 169 & N.-W. Okinawa Trough & $29^{\circ} 43^{\prime}-44^{\prime}$ & $127^{\circ} 37^{\prime}-40^{\prime}$ & $410-423$ \\
\hline 170 & N.-W. Okinawa Trough & $29^{\circ} 42^{\prime}-44^{\prime}$ & $127^{\circ} 48^{\prime}-49^{\prime}$ & $495-510$ \\
\hline 171 & N.-W. Okinawa Trough & $29^{\circ} 23.0^{\prime}-24.5^{\prime}$ & $127^{\circ} 30.9^{\prime}-32.0^{\prime}$ & $642-650$ \\
\hline 172 & N.-W. Okinawa Trough & $28^{\circ} 53^{\prime}-55^{\prime}$ & $127^{\circ} 18^{\prime}-19^{\prime}$ & $820-830$ \\
\hline 173 & N.-W. Okinawa Trough & $28^{\circ} 50^{\prime}-51^{\prime}$ & $127^{\circ} 14^{\prime}-16^{\prime}$ & $700-740$ \\
\hline 174 & N.-W. Okinawa Trough & $28^{\circ} 48.2^{\prime}-49.8^{\prime}$ & $127^{\circ} 03.7^{\prime}-05.5^{\prime}$ & $425-440$ \\
\hline 175 & N.-W. Okinawa Trough & $28^{\circ} 45^{\prime}-47^{\prime}$ & $127^{\circ} 07^{\prime}-08^{\prime}$ & $530-542$ \\
\hline 176 & N.-W. Okinawa Trough & $28^{\circ} 42^{\prime}-46^{\prime}$ & $127^{\circ} 09^{\prime}-10^{\prime}$ & $500-535$ \\
\hline 177 & N.-W. Okinawa Trough & $28^{\circ} 40^{\prime}-43^{\prime}$ & $127^{\circ} 12^{\prime}-14^{\prime}$ & $750-755$ \\
\hline 178 & N.-W. Okinawa Trough & $28^{\circ} 34^{\prime}-36^{\prime}$ & $127^{\circ} 09^{\prime}-12^{\prime}$ & $800-910$ \\
\hline 179 & N.-W. Okinawa Trough & $28^{\circ} 26.8^{\prime}-28.2^{\prime}$ & $127^{\circ} 07.5^{\prime}-09.8^{\prime}$ & 1,000 \\
\hline 180 & N.-W. Okinawa Trough & $27^{\circ} 45.5^{\prime}-46.0^{\prime}$ & $126^{\circ} 16.5^{\prime}-17.0^{\prime}$ & $490-500$ \\
\hline 181 & m. Okinawa Trough & $28^{\circ} 38.9^{\prime}$ & $128^{\circ} 12.5^{\prime}$ & 1,130 \\
\hline 182 & S. Okinawa Trough & $25^{\circ} 37.7^{\prime}-37.1^{\prime}$ & $122^{\circ} 53.1^{\prime}-53.6^{\prime}$ & $560-692$ \\
\hline 183 & S. Okinawa Trough & $25^{\circ} 17.1^{\prime}-26^{\circ} 15.7^{\prime}$ & $124^{\circ} 46.8^{\prime}-47.4^{\prime}$ & $910-990$ \\
\hline 184 & S. Okinawa Trough & $24^{\circ} 15^{\prime}$ & $123^{\circ} 30^{\prime}$ & 400 \\
\hline 185 & off S.E. Kyushu & $31^{\circ} 12.0^{\prime}$ & $131^{\circ} 42.4^{\prime}$ & 1,125 \\
\hline 186 & Tokara Strait & $29^{\circ} 13.7^{\prime}$ & $129^{\circ} 59.6^{\prime}$ & 1,240 \\
\hline 187 & E. of Yoron Isl. & $27^{\circ} 06.7^{\prime}-06.8^{\prime}$ & $128^{\circ} 41.8^{\prime}-41.9^{\prime}$ & $870-945$ \\
\hline 188 & E. of Miyako Isl. & $24^{\circ} 43.4^{\prime}-47.0^{\prime}$ & $126^{\circ} 26.3^{\prime}-28.0^{\prime}$ & $1,675-1,710$ \\
\hline 189 & S. of Iriomote Isl. & $23^{\circ} 41.3^{\prime}-42.3^{\prime}$ & $123^{\circ} 45.2^{\prime}-45^{\circ} 8^{\prime}$ & $3,436-3,452$ \\
\hline
\end{tabular}


Table 8. Species occurrences at the localities in the bathyal region.

As for the symbols, refer to Tab. 1.

*I-S.W. of Bono-misaki, $360 \mathrm{~m}$ (Mortensen, 1928b)

*II-off Kagoshima Bay, $274 \mathrm{~m}$ (A. Agassiz and H.L. Clark, 1907b)

*III-off the Goto Group (Mortensen, 1943a)

*IV-S.W. of the Koshiki Group, 664-769 m (A. Agassiz and H.L. Clark, 1907b)

*V-S.W. of the Koshiki Group, $704 \mathrm{~m}$ (A. Agassiz and H.L. Clark, 1907b)

*VI-S.W. of the Koshiki Group, 704-1,296 m (A. Agassiz and H.L. Clark, 1907b)

*VII-S.W. of the Koshiki Group, 704-781 m (A. Agassiz and H.L. Clark, 1907b)

*VIII-off Kagoshima Bay, 792m (A. Agassiz and H.L. Clark, 1907b)

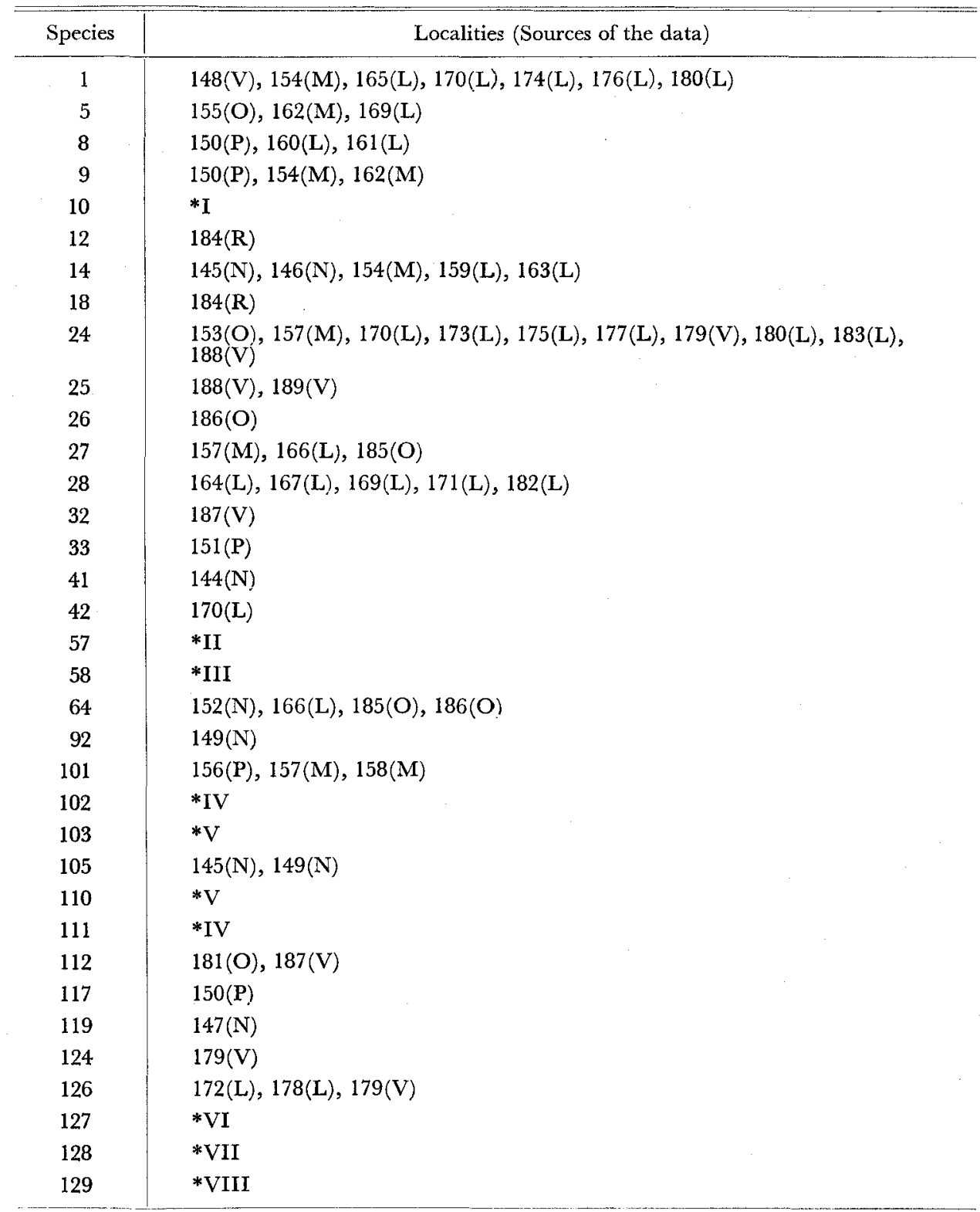




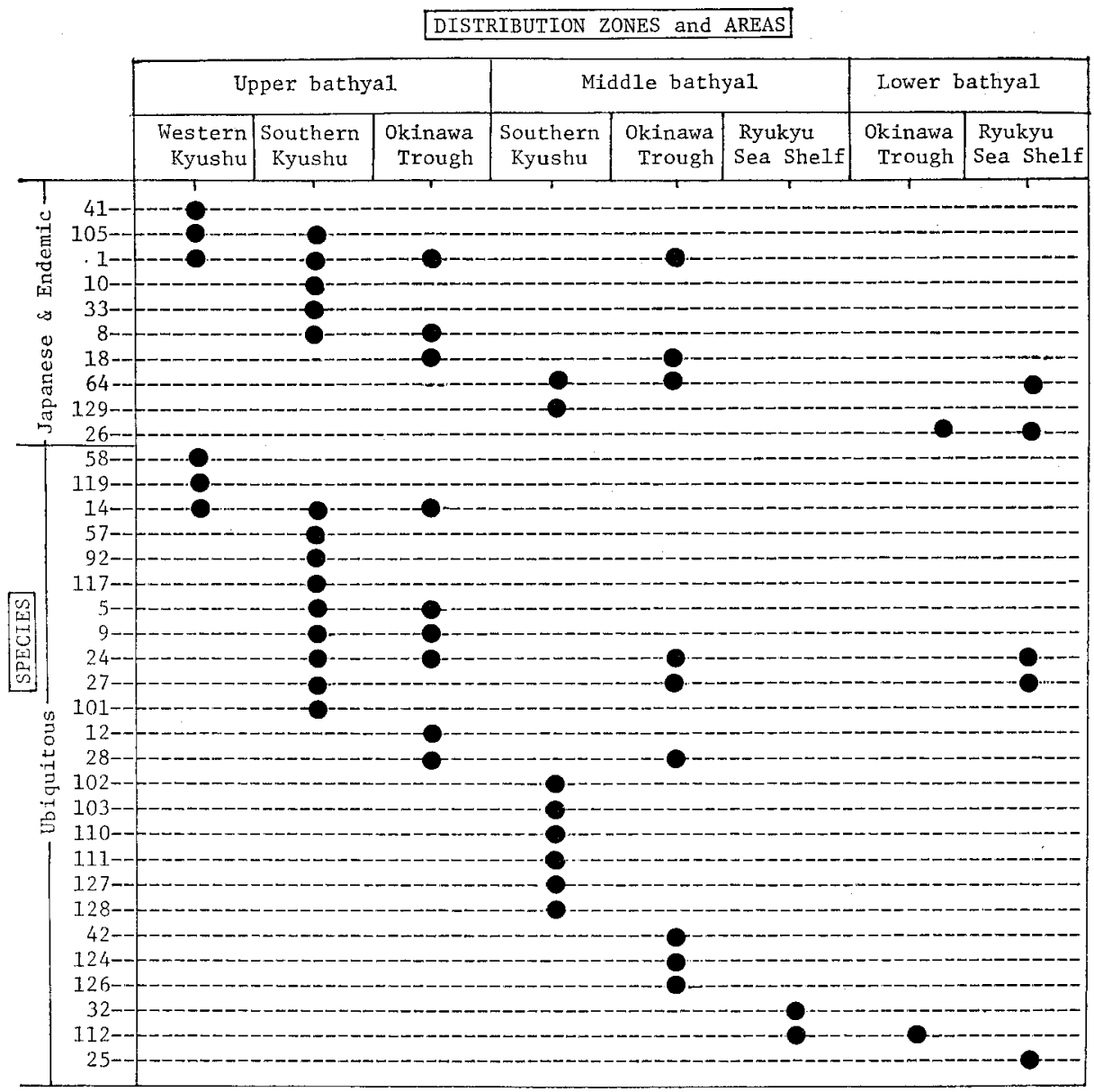

Figure 13. The vertical and regional distributions of the bathyal species. Species are shown by the species numbers given in the systematic list. Upper Bathyal, 200-500 m depths; Middle Bathyal, 500-1,000 m depths; Lower Bathyal, $1,000-3,500 \mathrm{~m}$ depths.

Western Kyushu, Sts. 144-148; Southern Kyushu, Sts. 149-158; Okinawa Trough, Sts. 159184; Ryukyu Sea Shelf, Sts. 185-189.

\begin{tabular}{ccr} 
Zone & Japanese & Ubiquitous \\
\hline Upper bathyal & $5 \mathrm{sp} .(27.8 \%)$ & $13 \mathrm{sp} .(72.2 \%)$ \\
Middle bathyal & $2 \mathrm{sp} .(12.5 \%)$ & $14 \mathrm{sp} .(87.5 \%)$ \\
Lower bathyal & $2 \mathrm{sp} .(33.3 \%)$ & $4 \mathrm{sp} .(66.7 \%)$ \\
\hline The whole bathyal & $7 \mathrm{sp} .(21.9 \%)$ & $25 \mathrm{sp} .(78.1 \%)$
\end{tabular}

It is notable that the ratio of the ubiquitous elements is markedly high throughout the bathyal zones. It will be much higher by findings of new localities for the Japanese and the endemic elements. 


\section{Discussion}

The faunal characteristics of the four zoogeographical subregions established for the intertidal \& upper sublittoral region may be explained fairly well from the hydrography of the East China Sea and its adjacent waters. The Ryukyu subregion where the fauna is purely tropical is bounded by the Kuroshio to the west and north. Throughout this subregion, the mean temperatures in the water shallower than a depth of $100 \mathrm{~m}$ do not fall below $20^{\circ} \mathrm{C}$ even in winter (Japan Oceanographic Data Center, 1978). The Kyushu subregion is always under the influence of the large and small branches of the warm currents. These carry many larvae of tropical species there. The occurrences of a fair number of subtropical species in this subregion are mainly attributable to the warm water of Kuroshio, while those of a considerable number of temperate species are attributable to the less warm coastal water of Kyushu. The Southern Korea subregion is surrounded by the cold coastal water of the Korea Peninsula, and it may explain the temperate fauna occurring there. The Taiwan subregion may be divided further into the northwestern and southeastern subregions. The former receives the coastal water of the Chinese Continent to some extent and the latter is completely within the Kuroshio area.

The faunal differences on the north and south sides of the Line 1 have been reported in distributional studies of caprellids (Arimato, 1973) and molluscs of the genus Haliotis (Uchida and Yamamoto, 1942).

The Line 2 between the Ohsumi and the Tokara Groups is a well-known zoogeographical line, the Watase's Line, which separates the Palaearctic and the Oriental region. It was originally drawn for land-dwelling animals, but it seems to be also valid for such marine animals as cirripedians (Utinomi, 1955), some bottomdwelling fishes (Kuroda, 1955), brachiopods (Nomura and Hatai, 1936), and shells (widely known among Japanese conchologists). For land faunas, this line exists as a reflection of the geological history. However, for marine faunas, the line seems to exist as a reflection of hydrography around it. The main stream of the Kuroshio flowing just along this line eastward seems to be an effective barrier against the southward distribution of the temperate and subtropical species.

It is interesting that such common intertidal species as Anthocidaris crassispina, Pseudocentrotus depressus, and Echinostrephus aciculatus occur discontinuously on the north side of the Line 2 and on the west side of the Line 3.

The faunal differences on the east and west sides of the Line 3 have not been adequately investigated, although a marine zoogeographical line has been drawn nearly the same location as the Line 3 by Utinomi (1955) in his distributional study on the cirripedians.

In the preceding chapters, I was not concerned with the fauna of the Chinese coast, where the water is in general shallower than $50 \mathrm{~m}$, and the fauna seems to be rather poor. In Table 9, the species known from the Chinese coastal waters connected with the East China Sea (from Chekiang to Fukien, and Taiwan Strait) are listed together with their localities based on Chang (1932), Chang et al. (1964), and 
Table 9. Echinoids of the Chinese coastal waters connected with the East China Sea (from Chekiang to Fukien and the Taiwan Strait).

Compiled from Chang (1932) and Chang et al. (1964), and revised specially for this paper by Dr. Y. Liao of the Institute of Oceanography, Academia Sinica, People's Republic of China in 1979.

\begin{tabular}{|c|c|}
\hline Species & Localities \\
\hline Temnopleurus toreumaticus (LEsKE) & Chekiang-Fukien \\
\hline Temnopleurus hardwickii (GRAY) & Chekiang and Taiwan Strait \\
\hline Temnopleurus reevesii (GRAY) & Chekiang-Fukien \\
\hline Temnotrema sculptum (A. Agassiz) & Chekiang-Fukien and Taiwan Strait \\
\hline Hemicentrotus pulcherrimus (A. AgAssiz) & Chekiang-Fukien \\
\hline Anthocidaris crassispina (A AGAssIz) & Chekiang-Fukien \\
\hline Arachnoides placenta (LINNAEUS) & Fukien \\
\hline Fibulariella acuta (YoshIWARA) & Chekiang-Fukien and Taiwan Strait \\
\hline Peronella lesueuri (L. Agassiz) & Fukien \\
\hline Laganum depressum (LEssoN) & Taiwan Strait \\
\hline Schizaster lacunosus (LINNAEUs) & Chekiang \\
\hline Lovenia elongata (GRAY) & Fukien \\
\hline Lovenia triforis (KOEHLER) & Chekiang \\
\hline
\end{tabular}

personal information from Dr. Y. Liao (1979).

It is worthy of notice that such species common in Kyushu as Anthocidaris crassispina and Hemicentrotus pulcherrimus also occur commonly in the Chinese coasts, and such species as Arachnoides placenta, Peronella lesueuri, and Laganum depressum which do not occur in Kyushu occur in the Chinese coasts. It is also suggested from Chang et al. (1964) that temperate species such as Strongylocentrotus nudus and Echinocardium cordatum, and a subarctic species such as Glyptocidaris crenularis occur in the north of Shantung on the Yellow Sea side, and many tropical species occur in the south of Kwangtung on the South China Sea side. Although the data are too few to discuss the fauna of the Chinese coast, the ratio of the temperate, the subtropical, and the tropical elements in the area connected with the East China Sea are: 15.4\% (2 sp.); $23.1 \%$ (3 sp.); $61.5 \%$ (8 sp.).

With regard to the lower sublittoral fauna, the present study revealed that the faunas on the insular shelves of Kyushu and those on the continental shelf are closely related with each other. It is evident that the Kuroshio exerts influence on Kyushu shelves and on the southern to northeastern areas of the continental shelf. The high percentage of tropical species in the submarine banks area apparently indicates a strong influence of the Kuroshio on the area. Okutani $(1963,1972)$ has also reported the strong influence of the Kuroshio on the molluscan fauna of the submarine banks around southern Kyushu and Izu-Shichito Islands.

The benthic surveys in the East China Sea have been carried out by Matsui and Taki (1950), Matsui (1951), Horikoshi et al. (1971), and Yamashita (1961, $1977 \mathrm{a}, 1977 \mathrm{~b}, 1977 \mathrm{c}, 1978,1979 \mathrm{a}, 1979 \mathrm{~b})$. In the studies on anomurans, Yamashita (1977a, 1977b) stated that such subarctic (Okhotsk-Bering) species as Pagurus ohotensis 
and Pagurus pectinatus occur abundantly in the Yellow Sea but never in the East China Sea which spreads south of the line drawn from Cheju Island to Shanghai. He stated further that a temperate species, Dardanus impressus, which does not occur in the former sea abundantly occurs in the latter. Similar patterns of distribution can be seen in his ecological studies on polychaetes (Yamashita, 1977c) which lists 104 species, on molluscs (Yamashita, 1978) with 172 species, on brachyurans (Yamashita, 1979a) with 92 species, and on echinoderms (Yamashita, 1979b) with about 61 species.

The present study reveals that the subarctic elements are completely absent from the whole region. Jensen (1974) recently cited "off Nagasaki" (probably the lower sublittoral zone) as one of the localities of an arctic (or subarctic) species, Strongylocentrotus pallidus (Sars), however, this is difficult to accept because the water off Nagasaki is under the influence of the Tsushima current and too warm to permit the occurrence of such an arctic species. One possible exception is a rather ubiquitous species, Echinocardium cordatum which occurs also in subarctic seas. It was defined as a temperate element in the present study because of its common occurrences in temperate waters.

In the present paper, new localities have been reported for many species without special notice. For example, Sperosoma giganteum (St. 186, Ryukyu sea shelf) has not been known outside the water off central Japan, and Kamptosoma asterias (Sts. 188 and 189, Ryukyu sea shelf) has been known only from two localities in the South and Central Pacific.

The number of echinoid species in the world seas may be estimated about 830 and about 165 in Japanese waters (Shigei, 1974). On that basis the 129 species recorded in this paper constitute $15.2 \%$ of the total from the world seas and $78.2 \%$ of the Japanese species. These values indicate that the echinoid fauna of the present region is extremely rich.

\section{Additional Remarks}

Several species which have been reported by other workers from the localities within the present region were not included in the present paper. Such species and the reasons for exclusion are as follows:

Order Echinoida

Suborder Temnopleurina

Family 'Temnopleuridae

Printechinus impressus Koehler was reported from off "Nakanokami-shima" which probably means Nakanougan-jima Isl., the Yaeyama Group, at a depth of $400 \mathrm{~m}$ by Ikeda (1940) who, however, showed neither figures nor descriptions. I think his identification is not reliable. This species has hitherto been known only from the Andaman Sea at depths of 110-135 m.

Desmechinus anomalus H.L. Clark was reported by H.L. Clark (1923) from the type locality designated as "China Sea" which may mean the South China Sea, 
Chinese coast, or even Yellow Sea.

Microcyphus maculatus A. Agassiz was stated to occur at Amami-Ohshima Isl. by Yoshiwara (1898), however, it is probably his misidentification as mentioned by Mortensen in his monograph (1943a, p. 155) "If Yoshiwara has had specimens from Riukiu (=Amami-Ohshima Isl.) before him, he has almost certainly misidentified them; as the species maculatus is known with certainty only from Mauritius; it is very unlikely that it should reappear at Japan". Although Hayasaka (1948) also reported its occurrence at Kao-hsiung, Taiwan based on his "strongly worn away" specimen (p. 29) with a figure, from which however, the species cannot be identified.

Microcyphus zigzag A. Agassiz was stated to occur at Kagoshima by Yoshiwara (1898). This is also probably an error in identification as mentioned by Mortensen (1943a, p. 171) "If he had specimens from there, it is no doubt a misidentification". This species has been known with certainty only from south Australia and Tasmania.

Suborder Echinina

Family Echinometridae

Heterocentrotus trigonarius (Lamarck) was stated to occur at Hungtouhsu, Taiwan by Hayasaka (1948), however, his description rather clearly indicates that his specimens are those of $H$. mammillatus with tapering spines.

Order Cassiduloida

Suborder Neolampadina

Family Neolampadidae

Anochanus sinensis Grube has been known by a single specimen from a vague, type locality, "China Sea".

Order Clypeasteroida

Suborder Laganina

Family Fibulariidae

Fibularia ovulum trigona Lamarck was stated to occur in Korea Strait by Mortensen (1948). I think his specimen probably belongs to Fibularia n. sp. of the present paper.

Fibularia volva A. Agassiz was stated to occur in "Channel of Formosa" by A. Agassiz (1872-74) and also in Taiwan by Yoshiwara (1900), however, I think these localities are unreliable as have been pointed out by Mortensen (1948a, P. 214).

Echinocyamus (Mortonia) australis (Desmoulins) was stated to occur in Formosa Sea by Nishiyama (1966) who, however, neither figured nor described specimens at all. The only locality hitherto known with certainty is Hawaii.

Family Laganidae

Laganum putnami A. Agassiz, probably a synonym of $L$. depressum, was stated to occur at "Oushima" by A. Agassiz (1872-74) and H.L. Clark (1914).

Laganum depressum Lesson was stated to occur at Amami-Ohshima Isl. and Taiwan by Yoshiwara (1900), however, I think he misidentified Peronella lesueuri as this species.

Laganum decagonalis Lesson was stated to occur at Kagoshima and Taiwan by Yoshiwara (1900), however, his L. decagonalis from Kagoshima is apparently Peronella japonica and that from Taiwan might be Peronella lesueuri. 
Peronella orbicularis (Leske) was stated to occur in Taiwan by Yoshiwara (1900). It is quite unreliable.

Peronella minuta (Meijere) was stated to occur in Kagoshima Bay by Nishiyama (1966), but he showed neither figures nor descriptions. I did not find this species during the present investigation.

Family Astriclypeidae

Echinodiscus auritus siamensis Mortensen was stated to occur in "southern Japan and Formosa" by Nishiyama (1966) who probably noted it based on Hayasaka (1948).

Order Spatangoida

Suborder Spatangina

Family Schizasteridae

Periaster fragilis A. Agassiz and H.L. Clark, or Hypselaster fragilis (A. Agassiz and H.L. Clark) is a vague species which was described from a single, immature specimen from off the Koshiki Group at a depth of $715 \mathrm{~m}$ (A. Agassiz and H.L. Clark, 1907b). About this species, Mortensen mentioned (1951, p. 321) “The only specimen known being a young one, still without genital pores, it is really quite unidentifiable. There is no certainty at all that it is a Hypselaster; but the statement that below the periproct there is a faint indication of an anal fascilole indicate that it is a Schizasterid".

Family Spatangidae

Spatangus altus Lütken has been known from a vague, type locality "China Sea".

Spatangus pallidus H.L. Clark was stated to occur in "off Kyushu" by Nishiyama (1966), but it is uncertain that he really examined the specimens. I did not find this species during the present investigation.

Spatangus luetkeni A. Agassiz was stated to occur in Taiwan by Yoshiwara (1900). Further information will be needed.

Maretia tubderculata A. Agassiz and H.L. Clark is uncertain species which was described based on a single, immature specimen from Korea Strait at a depth of $108 \mathrm{~m}$. It may belong to Lovenia rather than to Maretia as Mortensen has stated (1951, p. 45).

Family Loveniidae

Lovenia subcarinata (Gray) was stated to occur in Kagoshima Bay by Yoshiwara (1900), however, it is unreliable. He reproduced A. Agassiz's figures when he figured this species in his "Japanese Echini".

Pseudolovenia hirsuta A. Agassiz and H.L. Clark was reported by A. Agassiz and H.L. Clark (1907b) from off the Koshiki Group at depths of 664-731 m. Mortensen stated (1951, p. 127) "The identification is not beyond doubt, the specimens being young, so that for the present, at least, we are not entitled to state that it occurs also in Japanese seas".

Family Asterostomatidae

Palaeotrema loveni (A. Agassiz) was stated to occur in Kagoshima Bay by Nishiyama (1966). It is probable that he noted the locality without examination of the specimens. His source of information is unknown. 


\section{Summary}

1. 112 echinoid species were found from the East China Sea and the coastal waters of Southern Korea, Kyushu, Ryukyu, and Taiwan through my examination of specimens collected by various workers from 189 localities in depths of 0-3,452 m. An additional 17 species reported in the past was added to them and the faunal study was made based on distributional data of a total of 129 species.

2. For the intertidal \& upper sublittoral region, the following three zoogeographical lines, and four subregions were established:

Lines; 1-between the Korea Peninsula and the Cheju Island-Tsushima Group, 2-between the Ohsumi Group and the Tokara Group, and 3-between the Yaeyama Group and Taiwan.

Subregions; 1-Southern Korea, 2-Kyushu, 3-Ryukyu, and 4-Taiwan.

In these subregions, tropical elements dominated except in Southern Korea. They were found in increasing order in Southern Korea, Kyushu, Taiwan, and Ryukyu where the fauna was completely tropical. Subtropical elements were found in increasing order in, Southern Korea, Taiwan, and Kyushu, but not in Ryukyu. Temperate elements were not found in Taiwan and Ryukyu.

3. The lower sublittoral fauna was rather uniform throughout the whole region except the submarine banks, where tropical elements dominated distinctly and the fauna was fairly unique.

4. The bathyal fauna had a high ratio of ubiquitous elements.

5. No subarctic elements were found throughout the faunas.

\section{Acknowledgments}

I wish to express my gratitude to the following persons for placing their valuable specimens at my disposal. Without their specimens, the present study could not have been carried out: Dr. Hideo Yamashita of the Seikai Regional Fisheries Research Laboratory; Dr. Takashi Okutani of the National Science Museum; Dr. Katsura Oyama of the Toba Aquarium; Mr. Shuzo Kishida and Mr. Tadahiro Kitajima of the Seikai Regional Fisheries Research Laboratory; Mr. Tohru Imaoka of the Seto Marine Biological Station, Kyoto University; Professor Ki Won Kim of the Department of Biology, Liberal Arts and Science College, Chonnam University; Dr. Ten Shau Tan of the Department of Zoology, National Taiwan University; Associate Professor Moritaka Nishihira of the Department of Zoology, Faculty of Science, Kyoto University; Professor Masuoki Horikoshi, Dr. Hiroshi Mukai and Mr. Suguru Ohta of the Department of Marine Ecology, Ocean Research Institute, Tokyo University; Professor Kiyoshi Yamazato of the Department of Biology, Faculty of Science, Ryukyu University; Professor Taiji Kikuchi of the Amakusa Marine Biological Station, Kyushu University; Mr. Kinzo Matsubayashi of the Biological Society of Nagasaki Prefecture; Dr. Yoshiaki Tominaga of the Department of Zoology, University Museum, Tokyo University; Dr. Takao Yamaguchi of the Aitsu Marine 
Biological Station, Kumamoto University. I am also grateful to the late Dr. Hayato Ikeda whose large collections were used in the present study.

I am indebted to the following persons for their assisting me in my field surveys; Director Kunihiko Kano of the Kagoshima Prefectural Fisheries Research Station; Mr. Akinobu Yamaguchi of the Tarumizu Branch Station of the Kagoshima Prefectural Fisheries Research Station; Mr. Saburo Ohki of the Kumage Branch Office of the Kagoshima Prefectural Office; Mr. Goichi Koga of the Kami-Yakucho Branch Office of the Kagoshima Prefectural Fisheries Research Station; Mr. Hideo Nakamura of the Sesoko Marine Biological Station, Ryukyu University; Staffs of the Yaeyama Branch Station of the Okinawa Prefectural Fisheries Research Station; Staffs of the Kumage Branch Office of the Kagoshima Prefectural Office.

Thanks are also due to the following persons who kindly assisted me in various ways with this research; Dr. Katsuhisa Minci and Professor Teruaki Uchida of the Department of Zoology, Faculty of Agriculture, Kyushu University; Professor Edward Cutler of the Department of Biology, Utica College, Syracuse University; Professor Eiji Harada of the Seto Marine Biological Laboratory, Kyoto University; Professor Chung-Ghia Huang of the Department of Zoology, National Taiwan University; Associate Professor Toshiro Saisho of the Faculty of Fisheries, Kagoshima University; Dr. Hidenobu Isa of the Department of Biology, Ryukyu University; Dr. Yoshihiro Hayashi of the Amami Laboratory of Medical Zoology, Institute of Medical Science, Tokyo University; Professor Shozo Hayasaka of the Department of Geology, Faculty of Science, Kagoshima University; Dr. Naofumi Inoue of the Seikai Regional Research Laboratory; Dr. Masatsune Takeda of the Department of Zoology, National Science Museum; Mr. Yoshio Sanejima of the Ohshima Branch Office of the Kagoshima Prefectural Office; Mr. Naoteru Sakato of the Japan Hydrographic Association; Dr. Yulin Liao of the Institute of Oceanology, Academia Sinica, People's Republic of China; staffs of the Institute of Oceanography, Taiwan University; staffs of the Ohshima Branch Office of the Kagoshima Prefectural Office; staffs of the Imperial Household.

Finally, I wish to express my appreciation for many favours and encouragement given to me by Emeritus Professor Takashi Fujii and Professor Nobuo Egami of the Zoological Institute, Faculty of Science, Tokyo University.

\section{REFERENGES}

Agassiz, A. (1863) Synopsis of the echinoids collected by Dr. W. STIMPSON on the North Pacific exploring expedition under the commandant of Captains RINGGOLD and RODGERS. Proc. Acad. Nat. Sci. Phil., 15: 352-361.

- (1872-74) Revision of the Echini. Mem. Mus. Comp. Zool., 3 (1-2): i-xii $+1-378,69$ pls., (1873): 379-628, 28 pls., (1873): 3 (4): 629-762, 69 text-figs., 17 pls., (1874).

(1881) Report on the Echinoidea dredged by H. M. S. Challenger during the years 1873-76.

Rep. Challenger-Exped. Zool., 3 (9): $\mathrm{i}-\mathrm{vii}+\mathbf{1}-321$, pls. 1-45.

and H.L. Clark (1907a) Hawaiian and other Pacific Echini; the Cidaridae. Mem. Mus. Comp. Zool., 34: i-vii $+1-42$, pls. 1-42.

and - (1907b) Preliminary reports on the Echini collected in 1906, from May to December, among the Aleutian Islands, in Bering Sea, and along the coasts of Kamtchatka, 
Sakhalin, Korea, and Japan, by the U.S. Fish. Commission Steamer "Albatross", in Charge of Lieut. Commander, L.M. GARRETT, U.S.N. Commanding. Bull. Mus. Comp. Zool., 51 : 109139.

and - (1908) Hawaiian and other Pacific Echini; the Saleniidae, Arbaciidae, Aspidodiadematidae, and Diadematidae. Mem. Mus. Comp. Zool., 34: 43-134, pls. 45-59.

$\longrightarrow$ and - (1909) Hawaiian and other Pacific Echini; the Echinothuridae. Mem. Mus. Comp. Zool., 34: 135-204, pls. 60-89.

Arimoto, I. (1973) Studies on the distribution, ecology and other biological phenomena of caprellids around the Japanese waters I. Bull. Biogeogr. Soc. Jap., 29: 39-64.

Baranova, Z.I. (1957) Echinoderms of the Bering Sea. Invest. far eastern seas U.S.S.R. 4: 210-235.

Briggs, J.C. (1974) Marine zoogeography. 475 pp., McGraw-Hill, New York.

Chang, F.Y. (1932) Echinoidea of China Coast. Contr. Inst. Zool. Nat. Acad. Peiping, 1 (2): $11-$ 22, pls. 1-2.

Y. Liao, H. Go and H. Tei (1964) Echinoids. In illustrated encyclopedia of Chinese animals (Echinoderms), pp. 74-101. Kexue (Science) Publisher, Peking (in Chinese).

Clark, A.M. and F.W.E. Rowe (1971) Monograph of shallow-water Indo-West-Pacific echinoderms. Brit. Mus. Publ. (Nat. Hist.), 690: 1-238.

Clark, H.L. (1912) Hawaiian and other Pacific Echini; the Pedinidae, phymosomatidae, Stomopneustidae, Echinidae, Temnopleuridae, Strongylocentrotidae, and Echinometridae. Mem. Mus. Comp. Zool., 34: 205-383, pis. 90-121.

- (1914) Hawaiian and other Pacific Echini; the Clypeasterina; the Clypeasteridae, Arachnoididae, Laganidae, Fibulariidae, and Scutellidae. Mem. Mus. Comp. Zool., 46: 1-80, pls. 122-143.

(1917) Hawaiian and other Pacific Echini; the Spatangina; the Echinoncidae, Nucleolitidae, Urechinidae, Echinocorythidae, Calymnidac, Pourtalesiidae, Palaeostomatidae, Aeropsidae, Palaeopneustidae, and Spatangidae. Mem. Mus. Comp. Zool., 46: 81-284, pls. 144-161.

- (1925) A Catalogue of the Recent Sea-Urchins (Echinoidea) in the collection of the British Museum (Natural History). xxviii +250 pp., 12 pls., London.

Döderlein, L. (1885) Seeigel von Japan und Liu-Kiu Inseln. Archiv für Naturgesch., 51 (1): $73-112$. (1887) Die Japanischen Secigel: Theil I, Die Familien Cidaridae und Saleniidac. iv +59 pp., 11 pls., Stuttgart.

- (1906) Die Echinoiden der Deutschen Tiefsee-Expedition. Wiss. Ergebn. Deutsch. Tiefsee-Exped., "Valdivia", 5 (2): 61-290, text-figs. 1-46, pls. 9-50.

Durham, J.W. (1955) Classification of Glypeasteroid Echinoids. Univ. Calif. Publ., Geol. Sci., 31 : 73-198, pls. 3-4.

- and R.V. Melville (1957) A classification of Echinoids. J. Paleont., 31: 242-272.

H.B. Fell, A.G. Fischer, P.M. Kier, R.V. Melville, D.L. Pawson, and C.D. Wagner (1966) Echinodermata (Echinodiea). In treatise on invertebrate paleontology, 3 (1-2): U211-U633, Univ. Kansas Press.

Ekman, S. (1967) Zoogeography of the sea. xiv +417 pp., Sidwick and Jackson Ltd., London.

Hayasaka, I. (1948) Notes on the Echinoids of Taiwan. Bull. Oceanogr. Inst. Taiwan, 4: 1-36, pls. 1-6.

Hedgepeth, J.W. (1957) Classification of marine environment. Treatise on marine ecology and paleoecology, 1: 17-27 and 2: 93-100.

Horikoshi, M. (1957) Note on the molluscan fauna of Sagami Bay and its adjacent waters. Sci. Rep. Yokohama Nat. Univ., (Ser. II) (6): 37-64.

(1962a) Distribution of benthic organisms and their remains at the entrance of Tokyo Bay, in relation to submarine topography, sediments and hydrography. Nat. Sci. Rep. Ochanomizu Univ., 13 (2): 47-122.

(1962b) Warm temperate region and coastal-water area in the marine biogeography of the shallow sea system around the Japanese islands. Quaternary Res., 2 (2-3): 117-124.

(1969) Ecological-biogeography of the marine molluscan fauna of Japan. Fossils (18): 2-5 (in Japanese). 
(1971) Bathyal fauna on the deep-sea shelf and on the top of the rise and seamount. La Mer, 9: 46-53.

S. Gamo and M. Imajima (1971) Benthic communities on the continental shelf in the East China Sea-Preliminary report on the benthological survey in the Hakuho Maru Cruise KH-68-2. Proc. Sym. on Geological Problems of the seas around Kyushu (Assembly of 5 Geol. Socs.) [Kyushu Univ., Fukuoka] (in Japanese).

Ikeda, H. (1935a) On the echinoid genus Mespilia of Japan. Zool. Mag., 47:421-425, text-figs. 1-2 (in Japanese).

(1935b) Notes on the genus Echinarachnius of Japan. Bull. Sci. Fac., Kyushu Imp. Univ., 6: 202-208, pl. 4.

(1935c) A new Clypeaster from Japan. Annot. Zool. Japan., 15: 103-105, pl. 7.

figs.

(1936) Notes on a new Echinarachnius from Japan. Botany and Zoology, 4: 1231-1234, 4 text-

(1939a) A new species of Diadema from Japan. Rec. Oceanogr. Works in Japan, 10: 165-167, pl. 11 .

(1939b) A new genus and new species of the Cidaridae from the Bonin Islands (Cidaroida). Rec. Oceanogr. Works in Japan, 10: 160-164, pls. 7-10.

(1941) Preliminary report on Chorocidaris micca, gen. et sp. nov., from the Ryukyu Islands (Echinoidea, Cidaridae). Annot. Zool. Japan., 20: 85-86, pl. 6.

Inoue, E. (ed.) (1975) Goto-Nada Sea and Tsushima Strait Investigations, Northwestern Kyushu, 1972-1973. Cruise Rep. Geol. Survey Japan, 68 pp., Tokyo.

Inoue, N. (1974) Oceanography around western Japan. In Tsushima Current, pp. 27-41, Koseishakoseikaku, Tokyo (in Japanese).

Japan Oceanographic Data Center (ed.) (1978) Marine environmental altas-Northwestern Pacific Ocean II (Seasonal-Monthly), 10, 14, 18, Japan Hydrographic Association, Tokyo.

Jensen, M. (1974) The Strongylocentrotidae (Echinoidea), a morphologic and systematic study. Sarsia 57: 113-118.

Kier, P.M. (1962) Revision of the Cassiduloid Echinoids. Smith. Misc. Coll., 144 (4500): 262 pp., 181 text-figs., 44 pls.

Kikuchi, T. (ed.) (1963) Fauna and Flora of the sea around the Amakusa Marine Biological Laboratory, Part IV, Echinodermata, 13 pp., Amakusa M.B.S. Publ., Japan.

- (1968) The hydrographical condition of the waters near Amakusa, the western coast of Kyushu. Rep. Surv. Marine Park in Kumamoto Pref., 55-65 (in Japanese).

Kimoto, S. (1966) A methodological consideration of comparison of insect faunas based on the quantitative method. Esakia 5: 1-20.

Koehler, R. (1914) An account of the Echinoidea: Echinodermata of the Indian Museum; Part VIII, Echinoidea (1), 258 pp., 20 pls.

- (1922) An account of the Echinoidea: Echinodermata of the Indian Museum; Part IX, Echinoidea (2), 167 pp., 15 pls.

Kuroda, N. (1955) Distribution of Apodes (Pisces) and Watase's Line. Bull. Biogeograph. Soc. Japan, 16-19: 314-319.

Liao, Y. (1978) The Echinoderms of the Xisha Islands, Guandong Province, China. III, Echinoidea. Studia Marina Sinica, 12: 107-127, text-figs. 1-13, pls. 1-5.

Matsubayashi, K. (1973) Marine invertebrates of the Danjo Islands. In Fauna and Flora of the Danjo Islands, p. 1187, Nagasaki Biol. Soc., Japan.

Matsui, I. (1951) Relation between the trawling grounds and the benthic association in the East China Sea and the Yellow Sea. Bull. Jap. Soc. Sci. Fish., 16 (12): 159-167 (in Japanese).

- and T. Takai (1950) Quantitative analysis of the benthic communities in the East Ghina Sea and the Yellow Sea. Oceanogr. Cond. East China Sea and Yellow Sea (2): 35-71. Seikai Reg. Fish. Res. Lab. (in Japanese).

Meijere, J.C.H. De. (1903) Vorlaufige Beschreibung der neuen, durch die Sibnga-Expedition gesammelten Echiniden. Tjidschr. d. Nederland. Dierk. Vereen, Ser. 2, 8 (1): 1-16.

- (1904) Die Echinoidea der Siboga-Expedition. Siboga-Exped., Monograph 43, 252 pp., 23 pls., Leiden. 
Mortensen, Th. (1903) The Danish Ingolf-Expedition. 4(Echinoidea, Part 1): 1-198, 12 text-figs., pls. 1-21. (1904a) The Danish Expedition to Siam, 1899-1900, II, (Echinoidea, Part 1), Kongl. Dansk, Vidensk. Selsk. Skr. Ser. 7, 1: 11-124, 10 text-figs., pls. 1-7. (1904b) On some Echinothurids from Japan and Indian Ocean. Ann. Mag. Nat. Hist., Ser. 7, 14: 81-93, pls. 2-5.

(1907) The Danish Ingolf-Expedition, 4 (Echinoidea, Part 2): 1-200, pls. 1-19.

(1909) Die Echinoiden der Deutschen Südpolar-Expedition, 1901-1903. Deutsch. Sudpolar-Exped., 1901, 11: 1-113, pls. 1-19.

(1927) Report on the Echinoidea collected by the United State Fisheries Steamer "Albatross" during the Philippine Expedition, 1907-1910: Part 1, The Cidaridae. U.S. Nat. Mus., Bull. 100, 6: 243-312, 33 text-figs., pls. 48-80.

- (1928a) New Cidaridae: Papers from Dr. TH. MORTENSEN's Pacific Expedition. Vidensk, Meddel. Dansk, Naturhist. Foren., Kфbenhavn, 85: 65-74.

(1928b) A Monograph of the Echinoidea, 1 (Cidaroidea): 551 pp., 173 text-figs., 88 pls., Copenhagen.

- (1929) Reports of the biological survey of Mutsu Bay (Echinoidea), Sci. Rept. Tohoku Imp. Univ., Ser. 4 (Biol.), 4: 473-479, 2 text-figs., pl. 16 (1).

(1930a) Some new Japanese echinoids. Annot. Zool. Japan., 12: 387-394, 2 text-figs., pls. $1-4$.

(1930b) Moira lachesinella nom. nov. Vedensk. Meddel. Dansk. Naturhist. Foren., K $\phi$ benhavn, $90: 45$.

(1934a) New Echinoida (Stirodonta); Preliminary notice, Vidensk, Meddel. Dansk, Naturhist. Foren., Kфbenhavn, 98: 161-167.

(1934b) Echinoderms of Hong-Kong. Hong-Kong Naturalist, Supl., 3: 3-14, 9 textfigs., pls. 1-8.

(1935) A Monograph of the Echinoidea, 2 (Bothriocidaroida, Melonechinoida, and Stirodonta): 647 pp., 377 text-figs., 89 pls., Copenhagen.

(1940a) Report on the Echinoidea collected by the United States Fisheries Steamer "Albatross" during the Philippine Expedition, 1907-1910. Part 2: The Echinothuridae, Saleniidae, Arbaciidae, Aspidodiadematidae, Micropygidae, Diadematidae, Pedinidae, Temnopleuridae, Toxopneustidae, and Echinometridae. U.S. Nat. Mus., Bull. 100, 14 (1): 1-52.

- (1940b) A monograph of the Echinoidea, 3 (1) (Aulodonta): 370 pp., 197 text-figs., 77 pls., Copenhagen.

(1942) New Echinoidea (Camarodonta), Preliminary notice. Vidensk. Meddel. Naturhist. Foren., Kфbenhavn, 106: 225-232.

(1943a) A Monograph of the Echinoidea, 3 (2) (Camarodonta I; Orthopsidae, Glyphocyphidae, Temnopleuridae, and Toxopneustidae): 553 pp., 321 text-figs., 56 pls., Copenhagen.

- (1943b) A Monograph of the Echinoidea, 3 (3) (Camarodonta II: Echinidae, Strongylocentrotidae, Parasaleniidae, and Echinometridae): 446 pp., 215 text-figs., 66 pls., Copenhagen. (1948a) New Echinoidea (Cassiduloida, Clypeasteroida), Preliminary notice. Vidensk. Meddel. Dansk. Naturhist. Foren., K $\phi$ benhavn, 111:67-72.

(1948b) A Monograph of the Echinoidea, 4 (1) (Holectypoida, Cassiduloida), 363 pp., 326 text-figs., 14 pls., Copenhagen.

- _ (1948c) Report on the Echinoidea collected by the United States Fisheries Steamer "Albatross" during the Philippine Expedition, 1907-1910: Part 3, The Echinoneidae, Echinolampadidae, Clypeasteridae, Arachnoididae, Laganidae, Fibulariidae, Urechinidae, Echinocorythidae, Palaeostomatidae, Micrasteridae, Palaeopneustidae, Hemiasteridae, and Spatangidae. U.S. Nat. Mus., Bull. 100, 14: i-iii $+93-140$.

(1948d) A monograph of the Echinoidea, 4 (2) (Clypeasteroida; Clypeasteridae, Arachnoididae, Fibulariidae, Laganidae, and Scutellidae): iii +471 pp., 258 text-figs., 72 pls., Copenhagen.

(1950a) New Echinoidea (Spatangoida), Preliminary notice. Vidensk. Meddel. Dansk, Naturhist. Foren., Kфbenhavn, 112: 157-163. 
(1950b) A Monograph of the Echinoidea, 5 (1) (Spatangoida I; Protosternata, Meridosternata, Amphisternata I; The Palaeopneustidae, Palaeostomatidae, Aeropsidae, Toxasteridae, Micrasteridae, and Hemiasteridae) : v+432 pp., 315 text-figs., 25 pls., Copenhagen.

- (1951) A Monograph of the Echinoidea, 5 (2) (Spatangoida II; Amphisternata II; The Spatangidae, Loveniidae, Pericosmidae, Schizasteridae, and Brissidae): iv +593 pp., 286 textfigs., 64 pls., Copenhagen.

Nishiyama, S. (1966a) The echinoid fauna from Japan and adjacent regions, Part 1. Palaeont. Soc. Japan, Spec. Pap., $11:$ 1-277, pls. 1-18.

(1966b) The echinoid fauna from Japan and adjacent regions, Part 2. ibid., 13: 1-491, pls. $19-30$.

Nomura, K. (1939) Studies on the moth-fauna of the Island of Tanegashima, south Kyushu. Vol. Jubilare Prof. Sadao Yoshida, Osaka, 601-634.

- (1940) On the methods of comparison of faunae or florae, with special reference to the correlation method. Kyushu Univ., Bull. Fac. Agr., 9 (2): 235-262.

Nomura, S. and K. Hatai (1936) A note on the zoological provinces in the Japanese seas. Bull. Biogeogr. Soc. Jap., 6 (21): 208-214, pl. 13.

Ogawa, Y., T. Miita, A. Ichihara, Y. Hasegawa and N. Inoue (1978) Fluctuations of the Tsushima Current measured with the current drogue. Bull. Seikai Reg. Fish. Res. Lab., 51: 13-44.

Ohshima, H. (1934) Synopsis of the expedition of the Okinoshima Island (II), Kagaku, 4: 125-829 (in Japanese).

_L (1935) Animals of Yaeyama Islands. Botany and Zoology, 3: 444-446, figs. 22-23 (in Japanese).

(1949) Echinoidea. In illustrated encyclopedia of the fauna of Japan (revised ed.), pp. 576596, figs. 1671-1727, Hokuryukan, Tokyo.

Okutani, T. (1963) Preliminary notes on molluscan assemblages of the submarine banks around the Izu islands. Pacif. Sci., 17 (1): 73-89.

(1969) Synopsis of bathyal and abyssal megaloinvertebrates from Sagami Bay and the south off Boso Peninsula trawled by the R/V Soyo-Maru. Bull. Tokai Reg. Fish. Res. Lab., 57: $1-44$, pls. $1-8$.

- (1972) Molluscan fauna on the submarine banks Zenisu, Hyotanse, and Takase, near the Izu-Shichito Islands. Bull. Tokai Reg. Fish. Res. Lab., 72: 63-142.

Pérès, J.M. (1961) Oceanographie Bilogique et Bilogie Marine, I. La Vie Benthique. 542 pp., Presses Universitaires de France, Paris.

Philip, G.M. (1965) Classification of Echinoids. J. Paleont., 39: 45-62.

Ramsay, E.P. (1885) Catalogue of the Echinodermata in the Australian Museum. 390 pp., Sydney.

Roxas, H.A. (1928) Philippine littoral Echinoidea. Philip. J. Sci., 36 (2): 243-270, pls. 1-7.

Sasa, M., H. Takahashi, R. Kano and H. Tanaka (ed.) (1977) Animals of medical importance in the Nansei Islands in Japan. 410 pp., Shinjuku-Shobo, Tokyo.

Shigei, M. (1970a) Echinoids of the Bonin Islands. J. Fac. Sci., Univ. Tokyo, Sec. 4, 12: 1-22, textfigs. $1-6$, pls. $1-2$.

- (1970b) Marine invertebrate fauna of the Bonin Islands. The nature of the Bonin and the Volcano Islands, pp. 45 60, Higher Educ. Sci. Bureu, Ministr. Educ. and Cult. Properties Protect. Divis., Agen. Cult. Aff., Tokyo.

(1971) Distribution of littoral echinoids around the shores of the Kanto District and Izu Islands. Zool. Mag., 80: 477 (in Japanese).

(1973a) A check list of echinoids found in Sagami Bay with brief note on each species. J.

Fac. Sci., Univ. Tokyo, Sec. 4, 13: 1-33.

(1973b) A check list of echinoids of Suruga Bay, Part 1, littoral species. ibid., 13: 35-38.

(1973c) Preliminary report on the echinoid fauna near the Tateyama Marine Biological Station. Rep. Tateyama M.B.S., 1:4-5 (in Japanese).

(1974) Echinoids. In the Systematic Zoology 8(2)-Echinoderms: 208-332, Nakayama Book Company, Tokyo (in Japanese).

(1975a) A new species of the cidarid sea-urchin (Echinoidea; Cidaroida) from the East Ghina Sea. J. Fac. Sci., Univ. Tokyo, Sec. 4, 13: 321-328, Figs. 1-9. 
(1975b) A new species of a new genus of the arbaciid sea-ruchin (Echinoidea; Arbacioida) from the North Pacific, off Hachijo Island. ibid., 13: 329-332, figs. 1-9.

(1975c) A new species of the heart-urchin, an extant species of Brissopatagus (Echinoidea; Spatangoida), from Sagami Bay. ibid., 13: 333-339, figs. 1-16.

- (1977a) A new species of the echinothurid sea-urchin, Sperosoma nudum, from the North Pacific, off Central Japan. ibid., 14: 71-77, figs. 1-16.

(1977b) A new species of the aspidodiadematoid sea-urchin, Aspidodiadema intermedium,

from the East China Sea, off southern Japan. ibid., 14: 79-84, figs. 1-10.

and T. Okutani (1974) Echinoids collected by the R/V Soyo Maru for the past 18 years from Sagami Bay and around the Izu Islands. Zool. Mag., 83: 439 (in Japanese).

Simpson, G.G. (1943) Mammals and the nature of continents. Amer. J. Sci., 241: 1--31.

Sladen, W.P. (1879) On the Asteroidea and Echinoidea of the Korean Seas. J. Linn. Soc. London, Zool., 14: 424-445.

Tokioka, T. (1953) Invertebrate fauna of the intertidal zone of the Tokara Islands, V. Echinodermata. Publ. Seto Mar. Biol. Lab., 3 (2) : 144-146, figs. 1-2.

Tokunaga, S. (Yoshiwara, S.) (1904) Japanese Echini (Plates). Zool. Mag., 17: pls. 1-2.

(1905) Japanese Echini (Plates). ibid., 17: pls. 3-7.

(1906a) Japanese Echini (Plates). ibid., 18: pls. 8-13.

(1906b) Japanese Echini; Explanation of all plates. ibid., 18: appendix pp. (1)-(5).

(1907). Japanese Echini (Plates), ibid., 19: pls. 14-19.

(1908) Japanese Echini (Plates). ibid., 20: pls. 20-21.

Tsujita, T. (1957) The fisheries oceanography of the East China Sea and the Tsushima Strait. 1. The oceanographic structure and the ecological character of the fishing grounds. Bull. Seikai Reg. Fish. Res. Lab., 84: 1-47 (in Japanese).

Uchida, K. and T. Yamamoto (1942) On the distribution of Haliotis species in the Korean waters. Venus, 11 (4): 119-125.

Utinomi, H. (1954) A check list of echinoids found in the Kii region. Publ. Seto Mar. Biol. Lab., 3: 339-358, text-figs. 1 .

(1955) Studies on the Cirripedia of Japan, II, Geographical Distribution. Bull. Biogeograph. Soc. Japan, 16-19: 113-123.

(1956) Echinoidea. In coloured illustrations of seashore animals of Japan, pp. 113-119, pls. 57-60, Hoikusha, Osaka (in Japanese).

(1965) Echinoidea. In new illustrated encyclopedia of the fauna of Japan, 3: 64-81, text-figs. 196-257, Hokuryukan, Tokyo (in Japanese).

Yamaguchi, A., T. Nomura, S. Takano, N. Matsubara and Y. Kanno (1977) A survey on the fishing grounds of the abalone at the shore of Mage Island. Rep. Tarumizu Cultivation Center of the Kagoshima Pref. Fish. Res. St. 3: 109-135 (in Japanese).

Yamashita, H. (1961) Studies on the benthic organisms collected from the East China Sea and the Yellow Sea-I. Distribution of Crustacea, Gastropoda, Scaphopoda, Pelecypoda and Brachiopoda. Rep. Exped. Toko-Maru, 2: 126-177 (in Japanese).

(1977a) Studies on the benthic organisms collected from the East China Sea and the Yellow Sea-II. Distribution of two species of hermit crab, Pagurus ohotensis and Dardanus impressus. Bull. Seikai Reg. Fish. Res. Lab., 49: 1-17.

(1977b) Studies on the benthic organisms collected from the East China Sea and the Yellow Sea-III. Distribution of Pagurus pectinatus, a species of hermit crab living in the sponge. ibid., 49: $19-27$.

(1977c) Studies on the benthic organisms collected from the East China Sea and the Yellow Sea-IV. Distribution of polychaeta. ibid., 49:29-67.

(1978) Studies on the benthic organisms collected from the East China Sea and the Yellow Sea-V. Distribution of Shellfish, Gastropoda, Scaphopoda and Pelecypoda. ibid., 51: 45-95. (1979a) Studies on the benthic organisms collected from the East China Sea and the Yellow Sea-VI. Distribution of Brachyura. ibid., 52: 1-43. 
(1979b) Studies on the benthic organisms collected from the East China Sea and the Yellow Sea-VIII. Distribution of Echinoderms: Crinoidea, Ophiuroidea, Asteroidea, Echinoidea, Holothuroidea and Ascidiacea. ibid., 53: 51-86.

Yoshiwara, S. (1897) On two new species of Asthenosoma from the Sea of Sagami. Annot. Zool. Japon., $1: 5-11$, pl. 1 .

(1898a) Preliminary notice of new Japanese echinoids. ibid., 2: 57-61.

- (1898b) Japanese Echini (Text). Zool. Mag., 10: 1-8, 73-76, 145-158, 247-250, 328-331, 439-443 (in Japanese).

- (1900) Japanese Echini (Text). ibid., 12: 379-405 (in Japanese).

(1901) Echinoids of Okinawa Islands and Amami Islands. ibid., 13: 172-174 (in Japanese).

Zenkevitch, L.A. (1963) Biology of the Sea of the U.S.S.R. 955 pp., George Allen \& Unwin, London. 